\title{
Targeted therapy for hepatocellular carcinoma: novel agents on the horizon
}

\author{
Melchiorre Cervello', James A. McCubrey², Antonella Cusimano ${ }^{1}$, Nadia Lampiasi ${ }^{1}$, \\ Antonina Azzolina ${ }^{1}$, Giuseppe Montalto ${ }^{1,3}$ \\ ${ }^{1}$ Institute of Biomedicine and Molecular Immunology, "Alberto Monroy" National Research Council (C.N.R.) Via Ugo La Malfa \\ 153, 90146 Palermo, Italy \\ 2 Department of Microbiology and Immunology, Brody School of Medicine at East Carolina University, 600 Moye Blvd, \\ Greenville NC 27858, USA \\ ${ }^{3}$ Department of Internal Medicine and Specialties, University of Palermo, Via del Vespro 143, 90127 Palermo, Italy \\ Correspondence to: Melchiorre Cervello, email: cervello@ibim.cnr.it \\ Keywords: HCC, targeted therapy, VEGF, Ras/Raf/MEK/ERK, PI3K/AKt/PTEN/mTOR, signal transduction inhibitors, cancer \\ Received: March 22, 2012, $\quad$ Accepted: March 31, 2012, $\quad$ Published: March 31, 2012
}

Copyright: (c) Cervello et al. This is an open-access article distributed under the terms of the Creative Commons Attribution License, which permits unrestricted use, distribution, and reproduction in any medium, provided the original author and source are credited.

ABSTRACT:

Hepatocellular carcinoma (HCC) is the most common liver cancer, accounting for $\mathbf{9 0 \%}$ of primary liver cancers. In the last decade it has become one of the most frequently occurring tumors worldwide and is also considered to be the most lethal of the cancer systems, accounting for approximately one third of all malignancies.

Although the clinical diagnosis and management of early-stage HCC has improved significantly, HCC prognosis is still extremely poor. Furthermore, advanced HCC is a highly aggressive tumor with a poor or no response to common therapies. Therefore, new effective and well-tolerated therapy strategies are urgently needed.

Targeted therapies have entered the field of anti-neoplastic treatment and are being used on their own or in combination with conventional chemotherapy drugs. Molecular-targeted therapy holds great promise in the treatment of HCC. A new therapeutic opportunity for advanced HCC is the use of sorafenib (Nexavar). On the basis of the recent large randomized phase III study, the Sorafenib HCC Assessment Randomized Protocol (SHARP), sorafenib has been approved by the FDA for the treatment of advanced HCC. Sorafenib showed to be able to significantly increase survival in patients with advanced HCC, establishing a new standard of care. Despite this promising breakthrough, patients with HCC still have a dismal prognosis, as it is currently the major cause of death in cirrhotic patients. Nevertheless, the successful results of the SHARP trial underscore the need for a comprehensive understanding of the molecular pathogenesis of this devastating disease.

In this review we summarize the most important studies on the signaling pathways implicated in the pathogenesis of HCC, as well as the newest emerging drugs and their potential use in HCC management.

\section{INTRODUCTION}

Hepatocellular carcinoma (HCC) is the most common liver cancer, accounting for $90 \%$ of primary liver cancers. In the last decade it has become one of the most frequently occurring tumors worldwide and is also considered to be the most lethal of the cancer systems, accounting for approximately one third of all malignancies $[1,2]$. Distribution, however, is not homogeneous around the world, as important differences have been noted between countries, with most cases occurring in Eastern Asia and sub-Saharan Africa, while low rate areas are in North America, northern Europe and Australia [3, 4]. Changes in liver cancer incidence are beginning to be reported, namely a certain degree of reduction in the high-rate areas, particularly in China, thanks to the implementation of universal hepatitis $\mathrm{B}$ virus vaccination and limitation to aflatoxin B1 exposure $[5,6]$, while 
increasing incidences are being reported in low-rate areas, particularly in the United Kingdom and Australia [7].

By far the most frequent risk factor for $\mathrm{HCC}$ is liver cirrhosis (LC), this underlying disease being present in a variable proportion of cases, reaching a $90 \%$ rate in western countries [8]. The main etiological agents of LC are the hepatitis B (HBV) and hepatitis C (HCV) viruses, which together account for three quarters of all $\mathrm{HCC}$ cases worldwide. The diffusion of these viruses in the world reflects regional differences in the quantitative and qualitative (etiological) pattern of HCC. Other risk factors include aflatoxin B1 intake, alcohol consumption, non-alcoholic fatty liver disease (NAFLD) and some hereditary diseases, including hereditary hemochromatosis [9]. In the last few years a great body of evidence has been reported about the possibility that some severe forms of NAFLD may progress to HCC. NAFLD is usually part of the metabolic syndrome, found namely in patients with diabetes mellitus, hypertension, dyslipidemia, obesity and insulin resistance, which is becoming very frequent in western populations, due to their life style (sedentariness) and diet. It has also been called into question in many cases of HCC of "cryptogenetic" origin [10-12]. In particular, several studies suggest that obese patients are also at increased risk for several types of cancer, including HCC. Recently, a meta-analysis found that the relative risks (RR) for liver cancer were higher in obese (Body Mass Index, BMI $\geqslant 30$ ) than in overweight subjects (BMI $=25-30)$ [13].

HCC predominantly affects males, with a male to female ratio averaging $2: 1$ and 4:1 [9], although after the menopause no significant differences have been reported between the sexes [14]. For this reason sex hormones have been thought to play a possible role in neoplastic degeneration and various therapeutic evaluations based on anti-androgen or anti-estrogen agents have been performed, albeit with disappointing results [15].

We can therefore state that the pathogenesis of $\mathrm{HCC}$ is very complex and not completely clear. As in most cancers, HCC pathogenesis is a multistep process, involving sequential events such as chronic inflammation, hyperplasia and dysplasia and ultimately malignant transformation. It is a very long process, which usually takes even up to 30 years and during these years there are a number of epigenetic and genetic alterations, ultimately leading to an alteration in the molecular pathways. Several results indicate that there is no dominant pathway specifically altered in HCC [16]. Indeed, there are several subclasses of tumors presenting distinct molecular aberrations responsible for cell proliferation and survival, while other alterations present in almost all tumors involve limitless replicative potential, neoangiogenesis, and insensitivity to antigrowth signals and checkpoint disruption [16]. Recent discoveries in the complex networks involved in HCC proliferation, progression and survival have created many opportunities for targeted drugs and new therapeutic approaches to this disease. These new targets include signal transduction pathways, oncogenes and growth factors and their receptors.

In this review we will focus on the most frequently dysregulated signaling pathways implicated in the pathogenesis of HCC, as well as the newest emerging drugs and their potential use in the management of HCC.

\section{SIGNALING PATHWAYS}

The key signal transduction pathways that have been implicated in the pathogenesis of HCC include those mediated by epidermal growth factor (EGF)/EGF receptor (EGFR), vascular endothelial growth factor (VEGF)/VEGF receptor (VEGFR), platelet-derived growth factor (PDGF)/PDGF receptor (PDGFR), insulinlike growth factor (IGF)/IGF receptor (IGFR), and the Ras/Raf/mitogen-extracellular activated protein kinase kinase (MEK)/ extracellular signal-regulated kinase (ERK), Wnt/ß-catenin, and phosphatidylinositol-3kinase (PI3K)/phosphatase and tensin homologue deleted on chromosome ten (PTEN)/Akt/mammalian target of rapamycin (mTOR) signaling pathways (Figures 1-3). Further attention is required to determine the relevance and therapeutic potential of other pathways involved in liver carcinogenesis, such as the interleukin 6 (IL-6), signal transducer and activator of transcription (STAT) and Hedgehog signaling pathways.

Activation of these pathways will eventually lead to resistance to apoptosis, cell proliferation, the stimulation of angiogenesis, invasiveness and metastasis. In the past decade there has been significant breakthroughs in the discovery of interacting pathway components and insights into how mutations of these components can lead to aberrant signaling, uncontrolled proliferation and even sensitivity/resistance to targeted therapy [17-19]. Research has resulted in to the development of inhibitors that specifically target critical elements of these pathways as well as the concept that mutations at one signaling molecule in the pathways (e.g., EGFR, Ras, B-Raf) may prevent sensitivity to an inhibitor targeting a downstream component (e.g., Raf, MEK or PI3K) [20-25]. These studies indicate that the mutational status of key genes in the pathway (e.g., Ras, B-Raf) will have to be determined in cancer patients before applications of targeted therapy [17]. While sensitivity to EGFR inhibitors in non small cell lung carcinomas (NSCLC) is often due to mutations (L858R) or small deletions in exon 19 in the kinase domain, initial sensitivity to EGFR inhibitors may be lost due to subsequent mutations in the kinase domain. Other mutations in the kinase domain of EGFR prevent the induction of pro-apoptotic Bim in response to EGFR inhibitors. In some cases of NSCLC which have become resistant to EGFR inhibitors, they over express the c-Met proto-oncogene. Finally K-Ras mutations confer resistance to EGFR inhibitors (erlotinib, gefitinib or antibodies such 
as cetuximab). In some cases resistance to either Raf/ MEK or PI3K may occur as some upstream mutations (e.g., EGFR mutations) activate both Raf/MEK/ERK and PI3K/PTEN/Akt/mTOR signaling pathways. Treatment of cells with Ras mutations with certain mutant allele selective B-Raf inhibitors can result in Raf-1 activation. Dominant negative B-Raf mutations can still bind and activate Raf-1 if the cell has a mutant Ras allele. Finally some B-Raf inhibitor resistant cells overexpress various critical cell cycle regulatory molecules such as cyclin D. The various mechanisms of inhibitor resistance involving other components in these pathways are explained in more detail in McCubrey et al. [17]. Many recent studies are directed at increasing cancer patient survival by targeting these and other pathways in cancer cells.

Illustrations of the most important receptors and intracellular molecular signaling pathways, as well as sites of intervention with small molecule inhibitors and monoclonal antibodies are presented in Figures 1-2. Certain molecular-targeted agents are actually promiscuous (e.g. sorafenib, regorafenib, sunitinib, brivanib and others), i.e. they simultaneously target more than one molecule and this multiple targeting could enhance their therapeutic efficacy, while others act on a single target (e.g. AZD6244, AZD8055, everolimus and others) (Figure 1).

\section{EGF/EGFR PATHWAY}

The EGFR (also known as ErbB1 and Her1) belongs to the ERB family of receptor tyrosine kinases (RTKs), which includes ErbB2 (also known as Her2), ErbB3 (also known as Her3) and ErbB4 (also known as Her4). The members are all endowed with tyrosine kinase (TK) activity, with the exception of ErbB3. All members share a common structure, showing an extracellular ligand-binding domain, a transmembrane domain and an intracellular domain where the tyrosine kinase activity resides. EGFR forms homo- or heterodimers upon ligand binding. Dimerization results in auto-phosphorylation of EGFR with the subsequent activation of a number of downstream signaling pathways, including the PI3K/Akt/ mTOR and the Ras/Raf/MEK/ERK pathways (Figure 2). With the exception of ErbB2, which has no ligand, all the other members can bind a family of growth factors. Ligands for EGFR are EGF, TGF- $\alpha$, epigenin (EPG), amphiregulin (AREG), heparin-binding-EGF (HB-EGF), epirugulin (EREG) and $\beta$-cellulin (BTC) and the last three ligands are also able to bind to ErbB4/Her4. The

Figure 1: Relevant receptors and corresponding molecular targeted agents currently tested in preclinical and clinical HCC trials.

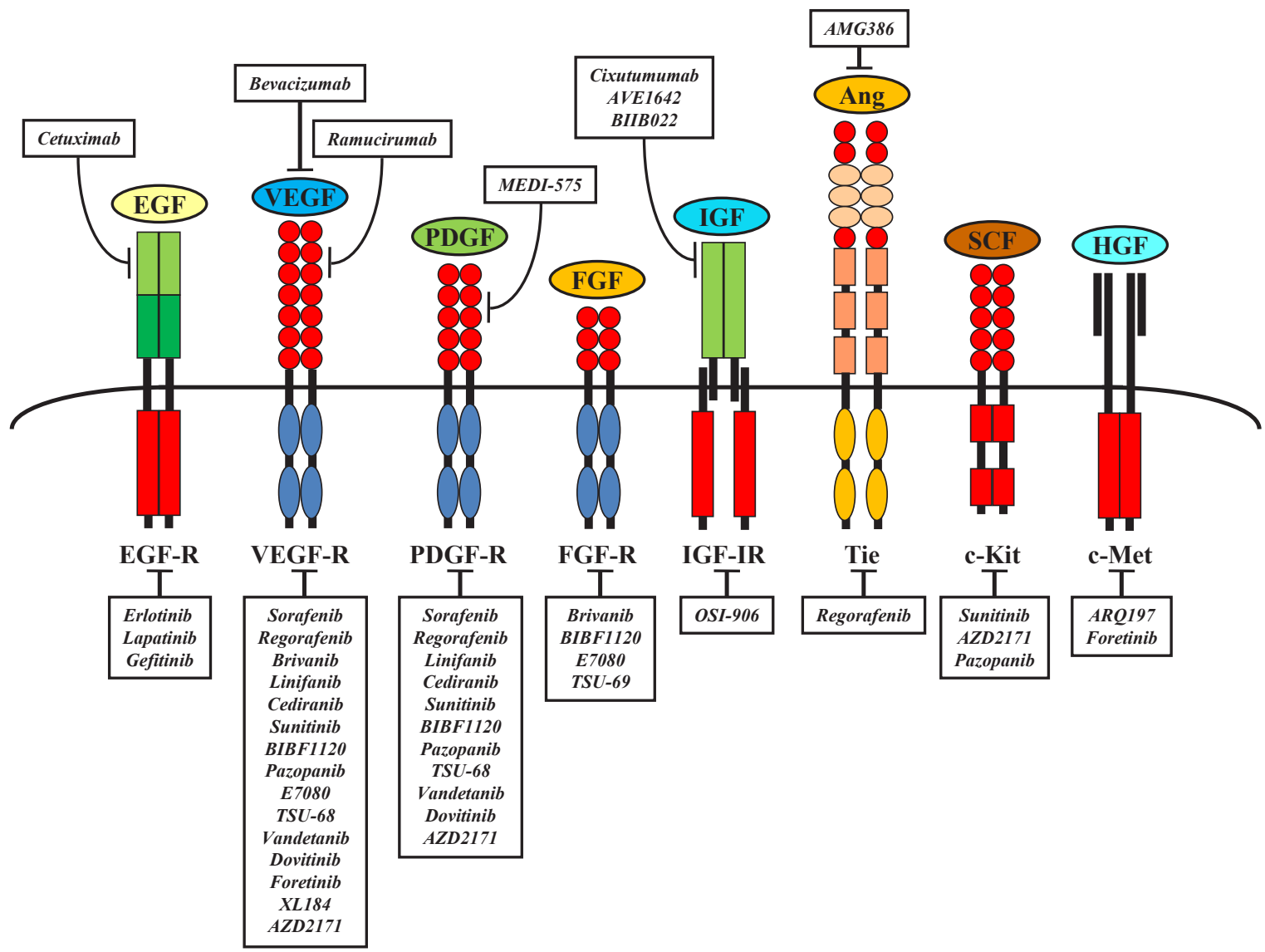


neuregulin (NRG) ligands NRG-1 and NGR-2 bind to both ErbB3/Her3 and ErbB4/Her4, whereas NGR-3 and NGR-4 only recognize ErbB4/Her4.

The receptor most studied in HCC is EGFR/ ErbB1. The rationale for targeting the EGFR pathway comes from the following observations: there is a high frequency of EGFR overexpression in HCC [26-29], and this overexpression has been associated with latestage disease, increased cell proliferation and degree of tumor differentiation [28-30]. In addition, activation of the EGFR pathway is a prognostic predictor of survival in patients with HCC [31]. Therefore, EGFR represents a good potential molecular target for the biological therapy of HCC.

The importance of EGF/EGFR signaling in the development of HCC has been confirmed in two recent studies showing that cirrhotic patients with high levels of serum and tissue EGF have a higher adjusted risk of developing HCC compared to cirrhotic patients with EGF levels comparable to healthy subjects [32, 33]. High levels of EGF are due to the presence of a single- nucleotide polymorphism in the $E G F$ gene, involving $A$ to $G$ transition at position 61 in the $5^{\prime}$ untranslated region of the $E G F$ gene (SNP rs4444903). The transcript of patients with SNP exhibited more than a 2-fold longer half-life than those from the $w t$ allele and serum EGF levels were 1.8 -fold higher in $G / G$ patients than $A / A$ patients, while liver EGF levels were 2.4-fold higher in $G / G$ patients than in $A / A$ patients. Whether higher EGF levels are associated with a greater risk of developing cirrhosis and a shorter time taken to develop cirrhosis were aspects not addressed by this study. However, the observation that the severity of cirrhosis did not differ between $A / A, A / G$, and $G / G$ patients argues against this possibility [32].

\section{RAS/RAF/MEK/ERK PATHWAY}

The Ras/Raf/MEK/ERK pathway, also known as the MAPK (mitogen-activated protein kinase) pathway, is a signaling pathway consisting of a kinase cascade regulated by phosphorylation and de-phosphorylation by specific kinases and phosphatases as well as GTP/GDP exchange

Figure 2: Schematic overview of PI3K/PTEN/Akt/mTOR and Ras/Raf/MEK/ERK signaling pathways stimulated after binding of a growth factor (GF) to a receptor tyrosine kinase.

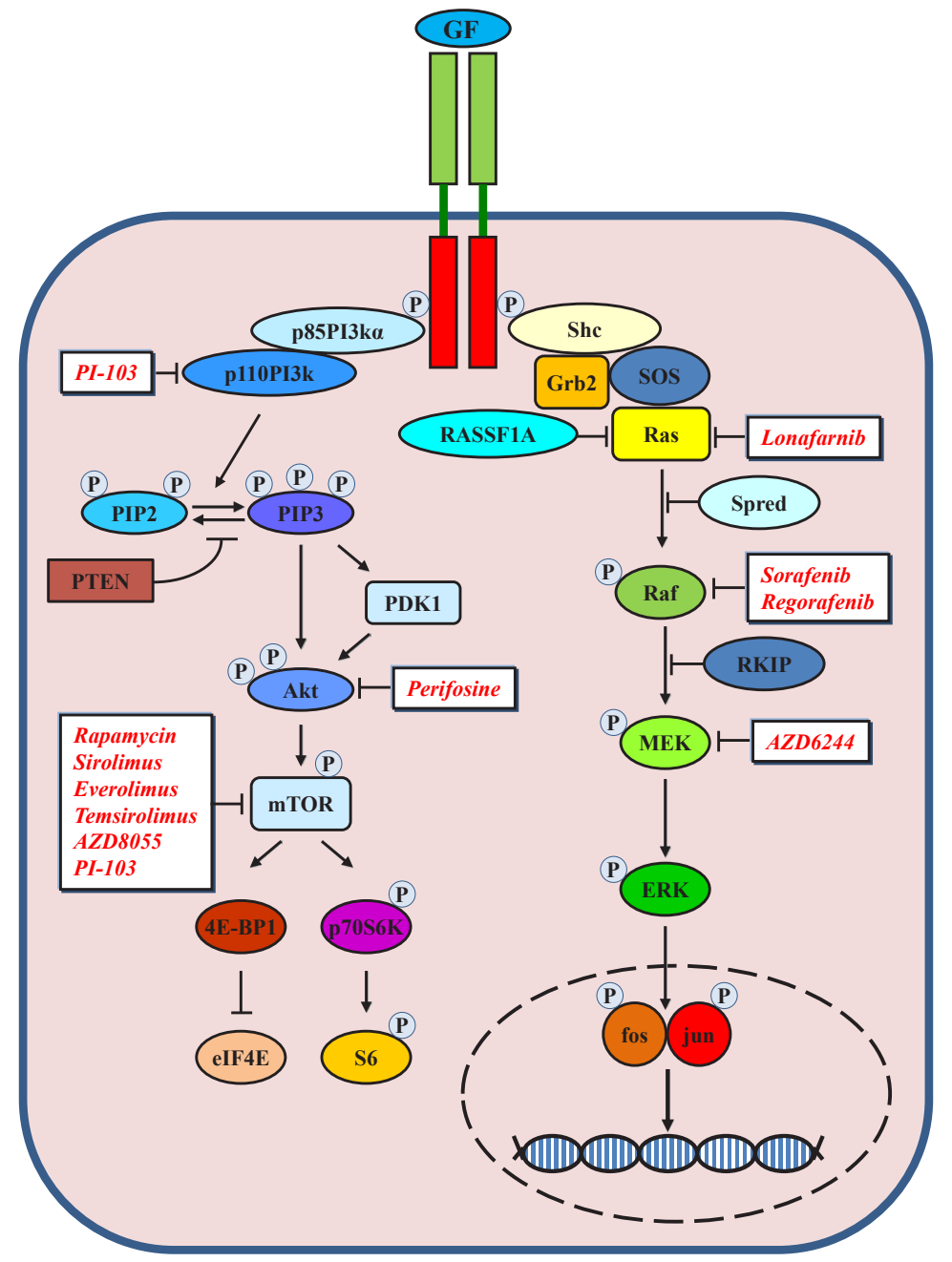


Table I: Trials of molecular targeted agents in $\mathrm{HCC}$

\begin{tabular}{|c|c|c|c|}
\hline Agent as monotherapy & Target & Design & $\begin{array}{l}\text { Clinicaltrials } \\
\text {.gov } \\
\text { Identifier }\end{array}$ \\
\hline Sorafenib (Nexavar, BAY43-9006; Bayer) & $\begin{array}{l}\text { BRAF, VEGFR-2, VEGFR-3, PDGFR- } \\
\text { b, c-KIT, FI'3 }\end{array}$ & Registered & \\
\hline Regofarenib (fluoro-sorafenib, BAY73-4506; Bayer) & $\begin{array}{l}\text { BRAF, VEGFR-2, VEGFR-3, PDGFR- } \\
\text { b, c-KIT, FIß, Tie2 }\end{array}$ & Phase I/II & $\begin{array}{l}\text { NCT01117623; } \\
\text { NCT01003015 }\end{array}$ \\
\hline Sunitinib (Sutent, SU11248; Pfizer) & $\begin{array}{l}\text { VEGFR-1 VEGFR-2, PDGFR-a, } \\
\text { PDGFR-b, c-KIT, FIt3, RET, CSF-1R }\end{array}$ & Phase III & NCT00699374 \\
\hline Brivanib (BMS-582664; Bristd-Meyers Squibb) & $\begin{array}{l}\text { VEGFR- 2, VEGFR-3, FGFR-2, FGFR- } \\
3\end{array}$ & Phase III & $\begin{array}{l}\text { NCT00858871; } \\
\text { NCT00825955 }\end{array}$ \\
\hline Linifanib (ABT-869, Abbott) & VEGFR-2, PDGFR-b, CSF-1R & Phase II & $\begin{array}{l}\text { NCT00517920; } \\
\text { NCT01009593 }\end{array}$ \\
\hline Pazopanib (GW786034, Votrient; GalxoSmithKine) & $\begin{array}{l}\text { VEGFR-1, VEGFR-2, VEGFR-3, } \\
\text { PDGFR-a, PDGFR-b, c-KIT }\end{array}$ & Phase I & NCT00370513 \\
\hline TSU-68 (SU6668; Taiho) & VEGFR-2, PDGFR- $\beta$, FGFR-1 & Phase I/II & NCT 00784290 \\
\hline Foretinib (XL880, GSK1363089; GlaxoSmithKline) & VEGFR-2; c-MET & Phase I/II & NCT00920192 \\
\hline E7080 (Eisai) & VEGFR-1, VEGFR-2, VEGFR-3 & Phase $\mathrm{I} / \mathrm{II}$ & NCT00946153 \\
\hline BIBF 1120 (Vargatef, Bœringer Ingelheim) & VEGFR-2, PDGFR-b, FGFR & Phase II & NCT00987935 \\
\hline XL184 (BMS907351; Bristd-Meyers Squibb) & VEGFR-2; c-MET & Phase II & NCT00940225 \\
\hline Dovitinib (TKI258; Novartis) & $\begin{array}{l}\text { VEGFR-1, VEGFR-2, VEGFR-3, } \\
\text { PDGFR-b, FGFR-3, FIt3, c-KIT, CSF- } \\
1 \text { R }\end{array}$ & Phase II & NCT01232296 \\
\hline Cediranib (Recentin, AZD2171; AstraZeneca) & VEGFR-2 & Phase II & $\begin{array}{l}\text { NCT00427973; } \\
\text { NCT00238394 }\end{array}$ \\
\hline Vandetanib (Zactima, ZD6474; AstraZeneca) & VEGFR, RET, EGFR & Phase I/II & $\begin{array}{l}\text { NCT00496509; } \\
\text { NCT00508001 }\end{array}$ \\
\hline Foretinib (XL880, GSK1363089; GlaxoSmithKline) & VEGFR-2, c-Met & Phase I & NCT00920192 \\
\hline Ramucirumab (IMC-1121B; ImClone Systems Inc) & VEGFR-2 & Phase II/II & $\begin{array}{l}\text { NCT00627042; } \\
\text { NCT01140347 }\end{array}$ \\
\hline Bevacizumab (Avastin; Genetech/Roche) & VEGF & Phase II & NCT00162669 \\
\hline Erlotinib (Tarceva, OSI774; Genetech) & EGFR & Phase I/II & $\begin{array}{l}\text { NCT00047346; } \\
\text { NCT00047333 }\end{array}$ \\
\hline Lapatinib (Tyverb, GW572016; GlaxoSmithKline) & EGFR, HER2/neu & Phase II & $\begin{array}{l}\text { NCT00107536; } \\
\text { NCT00101036 }\end{array}$ \\
\hline Gefitinb (Iressa, ZD1839; AtraZeneca) & EGFR & Pahse II & $\begin{array}{l}\text { NCT00071994; } \\
\text { NCT00282100 }\end{array}$ \\
\hline $\begin{array}{l}\text { Cetuximab (Erbitux, IMC-C225; Bristol-Meyers Squibb, Merck } \\
\text { Serono) }\end{array}$ & EGFR & Phase II & NCT00142428 \\
\hline OSI-906 (OSI Pharmaceuticals ) & IGF-1R, IR & Phase II & NCT01101906 \\
\hline Cixutumumab (IMC-A 12; ImClone Systems Inc) & IGF-1R & Phase II & NCT00639509 \\
\hline BIIB022 (Biogen-ldec) & IGF-1R & Phase I & NCT00555724 \\
\hline AVE1642 (Sanofi-Aventis) & IGF-1R & Phase I/II & NCT00791544 \\
\hline Everolimus (RAD001; Novartis) & mTOR & Phase $\mathrm{I} / \mathrm{II}$ & NCT00390195 \\
\hline Temsirolimus (Torisel; Wyeth Pharmaceuticals, Inc) & $\mathrm{mTOR}$ & Pahse II & $\begin{array}{l}\text { NCT01079767; } \\
\text { NCT01251458 }\end{array}$ \\
\hline AZD8055 (AstraZeneca) & mTOR & Phase I/II & NCT00999882 \\
\hline ARQ197 (ArQule, Inc) & c-Met & Phase I/II & $\begin{array}{l}\text { NCT00802555; } \\
\text { NCT00988741 }\end{array}$ \\
\hline MK-2206 (Merck \& Co., Inc.) & Akt & Phase II & NCT01239355 \\
\hline AZD6244 (ARRY-142886, Selumetinib; AstraZeneca) & MEK & Phase $1 / I I$ & $\begin{array}{l}\text { NCT00550719; } \\
\text { NCT00604721 }\end{array}$ \\
\hline
\end{tabular}


Table I Continued

\begin{tabular}{|c|c|c|}
\hline $\begin{array}{l}\text { Combination of } \\
\text { targeted agents }\end{array}$ & Design & $\begin{array}{c}\text { Clinicaltrials } \\
\text { gov } \\
\text { Identifier }\end{array}$ \\
\hline Sorafenib + Erlotinib & Phase III & NCT00901901 \\
\hline Sorafenib + AVE1642 & Phase I/II & NCT00791544 \\
\hline Sorafenib + BIBF 1120 & & NCT01004003 \\
\hline $\begin{array}{l}\text { Sorafenib + Panobinostat } \\
\text { (LBH589, Novartis) }\end{array}$ & Phase I & NCT00823290 \\
\hline Sorafenib + Cixutumumab & Phase I & $\begin{array}{l}\text { NCT01008566; } \\
\text { NCT00906373 }\end{array}$ \\
\hline Sorafenib + OSI-906 & Phase III & NCT01334710 \\
\hline Sorafenib + BIIB022 & Phase I & NCT00956436 \\
\hline Sorafenib + Temsirolimus & Phase I/II & $\begin{array}{l}\text { NCT01008917; } \\
\text { NCT01335074 }\end{array}$ \\
\hline Sorafenib + ARQ197 & Phase I & NCT00827177 \\
\hline Sorafenib + AZD6244 & Phase I/II & NCT01029418 \\
\hline Erlotinib + Bevacizumab & Phase II & $\begin{array}{l}\text { NCT } 01180959 ; \\
\text { NCT } 00242502 ; \\
\text { NCT } 00287222 ; \\
\text { NCT } 00365391\end{array}$ \\
\hline Erlotinib + AVE1642 & Phase I/II & NCT00791544 \\
\hline Erlotinib + Celecoxib & Phase I/II & NCT00293436 \\
\hline Bevacizumab + Everolimus & Phase II & NCT00775073 \\
\hline $\begin{array}{l}\text { Targeted agents in } \\
\text { combination with } \\
\text { cytotoxic therapy }\end{array}$ & Design & $\begin{array}{c}\text { Clinicaltrials } \\
. \text { gov } \\
\text { Identifier }\end{array}$ \\
\hline $\begin{array}{l}\text { Erlotinib + Gemcitabine- } \\
\text { Oxaliplatin (GEMOX) }\end{array}$ & Phase II & NCT00832637 \\
\hline Erlotinib + Docetaxel & Phase II & $\begin{array}{l}\text { NCT } 00047333 ; \\
\text { NCT } 00532441\end{array}$ \\
\hline $\begin{array}{l}\text { Cetuximab + Capecitabine- } \\
\text { Oxaliplatin (CAPEOX) }\end{array}$ & Phase II & NCT00483405 \\
\hline $\begin{array}{l}\text { Bevacizumab + transarterial } \\
\text { chemoembolis ation (TACE) }\end{array}$ & Phase II & NCT00280007 \\
\hline $\begin{array}{l}\text { Bevacizumab + Gemcitabine- } \\
\text { Oxaliplatin (GEMOX) }\end{array}$ & Phase II & NCT00142467 \\
\hline
\end{tabular}

proteins, adaptor proteins and scaffolding proteins (Figure 2 ). In response to a variety of cellular stimuli, including growth factor-mediated activation of receptor tyrosine kinases (RTKs), Ras assumes an activated GTP-bound state, leading to recruitment of Raf from the cytosol to the cell membrane, where it becomes activated, likely via a Src-family tyrosine kinase [20, 21, 34-36]. Activated Raf causes the phosphorylation and activation of MAP kinase extracellular signal-regulated kinases 1 and 2 (MEK1/MEK2), which in turn phosphorylate and activate extracellular signal-regulated kinases 1 and 2 (ERK1/ ERK2) at specific Thr and Tyr residues [37]. Activated ERK can translocate into the nucleus and phosphorylate additional transcription factors, such as Elk-1, CREB, Fos and globin transcription factor 1 (Gata-1) as well as others, which bind promoters of many genes, including growth factor and cytokine genes, which are important in promoting growth and preventing the apoptosis of multiple cell types [38-40].

Deregulation of the Ras/Raf/MEK/ERK pathway plays a key role in the pathogenesis of several human cancers [17, 41, 42], including HCC [21, 43-48]. Although mutations of Ras and Raf occur infrequently in $\mathrm{HCC}$, a recent study demonstrated that activation of the Ras pathway was observed in $100 \%$ of HCC specimens analyzed when compared with non-neoplastic surrounding tissue and normal livers. This increased expression of Ras coincided with the decreased expression of genes which serve to inhibit Ras expression, namely the Rasassociation domain family 1A (RASSF1A) and the novel Ras effector 1A (NORE1A). These genes may be suppressed due to aberrant methylation of their promoters [49]. In addition, activation of the Ras/Raf/MEK/ERK pathway in HCC may be due to the down-regulation of Ras inhibitors Sprouty and Sprouty-related protein with Ena/vasodilator-stimulated phosphoprotein homology-1 domain (Spred-1) and Spred-2 [50, 51]. It has been shown that the expression of Spred-1 and -2 in human HCC tissues is frequently lower than in the adjacent nontumor tissue and inversely correlates with the incidence of tumor invasion and metastasis [51]. Moreover, forced expression of Spred inhibited HCC cell proliferation both in vitro and in vivo, which was associated with reduced ERK activation, suggesting that Spred could be not only a novel prognostic factor but also a new therapeutic target for human HCC [51]. Recently, studies have also shown that down-regulation of Raf kinase inhibitor protein (RKIP) expression is a major factor in the activation of the ERK/MAPK pathway during human liver carcinogenesis $[52,53]$.

Deregulation of the ERK pathway has clinical importance in HCC. Activation of the ERK signaling pathway predicts poor prognosis in hepatocellular carcinoma [54]. The important role of ERK signaling has also been suggested for HCC progression in obese patients. A possible explanation for an associated risk for obesity and HCC comes from the study of Saxena et al., which for the first time demonstrated that leptin, a key molecule involved in the regulation of energy balance and body weight control, promotes HCC growth and invasiveness through activation of ERK signaling [55].

Other well known risk factors for HCC such as HBV and HCV infection also seem to utilize the Raf/MEK/ERK pathway for the control of hepatocyte survival and viral replication $[56,57]$. HBx, one of the four proteins encoded by the HBV genome, has been reported to be involved in liver carcinogenesis, with HBx expression activating the Ras, Raf, MAP kinase signaling cascade [56, 58-60]. Among the HCV components, the core protein has been reported to activate the Ras/Raf/MEK/ERK pathway and thereby might contribute to HCC carcinogenesis $[57,61$, 62]. Therefore, these studies suggested the possible use of the Raf/MEK/ERK pathway as a target in therapeutic 
approaches for the treatment of HCC resulting from HBV and HCV infection. Taken together, these data suggest that the Raf/MEK/ERK pathway may represent an important therapeutic target for the treatment of HCC in patients with differing etiologies that lead to the development of this aggressive tumor.

Activation of Ras/Raf/MEK/ERK signaling in HCC may result from up-regulation of IGF [63], aberrant upstream EGFR signaling [64] and other receptor signaling (i.e. VEGFR and PDGFR). An effective blockade of the Ras/Raf/MEK/ERK pathway can be achieved using small molecules, such as lonafarnib, sorafenib, regorafenib, AZD6244 and others (Figures 1 and 2). Drugs inhibiting components of the Ras/Raf/MEK/ERK pathway, with the exception of sorafenib, are still in the pre-clinical phase or in phase I/II clinical trials for HCC therapy (Table 1).

\section{PI3K/PTEN/AKT/MTOR PATHWAY}

The PI3K/PTEN/Akt/mTOR pathway is another key pathway in $\mathrm{HCC}$, its activation inducing cell proliferation and increasing survival. This pathway is activated after the binding of different growth factors to specific cell surface receptors, such as EGFR and IGF-1R (Figure 2). $\mathrm{PI} 3 \mathrm{~K}$ is a heterodimeric protein with an $85-\mathrm{kDa}$ regulatory subunit and a $110-\mathrm{kDa}$ catalytic subunit (PIK3CA). PI3K serves to phosphorylate a series of membrane phospholipids including PtdIns(4)P and PtdIns(4,5) $\mathrm{P}_{2}$, thereby forming the second messenger lipids $\operatorname{PtdIns}(3,4)$ $\mathrm{P}_{2}$ (PIP2) and PtdIns $(3,4,5) \mathrm{P}_{3}$ (PIP3). PIP3 then activates the phosphotidylinositide-dependent kinases (PDKs) which are responsible for activation of serine-threonine kinase Akt/protein kinase B (PKB) (Figure 2). Once activated, Akt leaves the cell membrane to phosphorylate intracellular substrates, including caspase-9 [65], the pro-apoptotic molecule BAD [66, 67], GSK-3 $\beta$ [68], and kinase IкB (IKK) [69]. When these targets are phosphorylated by Akt, they may either be activated or inactivated (e.g. phosphorylated BAD is inactive), but the final result is to promote cell survival. As well as intracellular substrates, Akt is able to target a number of transcription factors. In fact, after activation Akt is able to translocate into the nucleus [70] where it affects the activity of a number of transcriptional regulators, such as cAMP response element-binding (CREB) [71], E2F [72, 73], NF-кB (via IKK) [69], and the forkhead transcription factors [74-77].

Activated Akt positively modulates mTOR function. mTOR phosphorylates components of the protein synthesis machinery, such as the serine-threonine kinase p $70^{\mathrm{S} 6}$ (40S ribosomal protein kinase) and the translation repressor eukaryotic initiation factor 4E-binding protein-1 (4E-BP1), both regulating the translation of important factors involved in cell proliferation (such as c-myc, cyclic D1 and $\mathrm{pRb}$ ) and angiogenesis (such as HIF1- $\alpha$ ).

Negative regulation of the PI3K pathway is primarily accomplished through the action of the PTEN tumor suppressor protein. PTEN in turn dephosphorylates PIP3, thus inhibiting the PI3K/Akt pathway.

Activation of $\mathrm{PI} 3 \mathrm{~K} / \mathrm{PTEN} / \mathrm{Akt} / \mathrm{mTOR}$ signaling through the mutation, inactivation or silencing of pathway components occurs in various malignancies, including HCC [78]. Deregulation of this pathway has been documented to have clinical importance in HCC. For example, recent data from a genomic sequence of $\mathrm{HCC}$ samples identified mutations in $P I K 3 C A$, an upstream regulator of Akt, in $50 \%$ of patients with poor prognosis and survival length $<3$ years following partial liver resection, whereas only $10 \%$ of the HCC patients with a good prognosis had a mutation in PIK3CA [79]. Activation of Akt is a risk factor for early disease recurrence and poor prognosis in patients with $\operatorname{HCC}[54,80]$. Several mechanisms may be responsible for the activation of Akt. The high frequency of PIK3CA mutations and/or its upregulation in patients with a shorter survival might be responsible for the Akt hyperactivation found in HCC with poor prognosis [80]. Selective epigenetic silencing of multiple inhibitors of the Ras pathway also seems to be responsible for the activation of Akt found in HCC [78]. Moreover, impaired expression of PTEN is involved in the regulation of Akt activity. Activation of Akt signaling and a reduced expression of PTEN has been reported in $40-60 \%$ of human HCC [80].

The best evidence strongly supporting the connection between PTEN suppression and liver carcinogenesis comes from genetic studies. All mice with PTEN-deficient hepatocytes exhibited liver adenomas and $66 \%$ of them developed HCC [81]. In these mice, hepatocytes were hyperproliferative and displayed an abnormal activation of Akt [81]. Furthermore, although mutations in the PTEN gene rarely occur in $\mathrm{HCC}$, frequent loss of heterozygosity of the PTEN allele has been identified in $20-30 \%$ of HCC patients [82-85]. In addition, downregulation of PTEN expression may be partly due to PTEN promoter methylation [86]. Recent studies have also demonstrated that PTEN expression plays a critical role in $\mathrm{HCC}$ progression and patient survival. Patients with a high PTEN expression had a significantly better overall survival than patients with a low expression $[87,88]$.

An important role of the PI3K/PTEN/Akt/mTOR pathway has been suggested for $\mathrm{HCC}$ progression in obese patients. In the study by Saxena et al., leptin not only promoted HCC growth and invasiveness through activation of ERK pathway, but also through activation of PI3K/PTEN/Akt/mTOR signaling [55]. The other wellknown risk factors, $\mathrm{HBV}$ and $\mathrm{HCV}$, also seem to utilize the PI3K/PTEN/Akt/mTOR pathway to control hepatocyte survival and viral replication $[89,90]$. It has been reported that HBx expression downregulated PTEN expression in hepatocytes [91]. In contrast, PTEN expression in liver cells downregulated $\mathrm{HBX}$-induced PI3K and Akt activities [92]. Therefore, these studies suggest the possible use of 
PTEN as a target in therapeutic approaches, at least for the treatment of HCC caused by HBV infection.

Recent studies have demonstrated that mTOR inhibition shows a remarkable activity against a wide range of human cancers in vitro and human tumor xenograft models. The mTOR pathway is known to be upregulated in a subset of HCC patients [93]. In this study $15 \%$ of HCC displayed overexpression of phosphomTOR, whereas $45 \%$ of HCC had increased expression of p70 S6K, which correlated with tumor nuclear grade. The importance of the mTOR pathway in HCC was confirmed by Llovet's group in a comprehensive study with $314 \mathrm{HCC}$ and 37 non-tumor tissues using a series of molecular techniques to assess mutation, DNA copy number changes, messenger RNA and gene expression, as well as protein activation [94]. Aberrant activation of mTOR signaling (p-RPS6) was present in half of the cases and was associated with IGF pathway activation, EGF up-regulation, PTEN dysregulation and chromosomal gains in the rapamycin-insensitive companion of mTOR (RICTOR) (25\% of patients). Furthermore, positive p-RPS6 staining correlated with HCC recurrence after resection [94]. Overall, these data support efforts to target mTOR signaling in liver cancer patients.

Taken together, these data suggest that the PI3K/ PTEN/Akt/mTOR pathway may represent an important therapeutic target for $\mathrm{HCC}$ treatment in patients with differing etiologies that lead to the development of this aggressive tumor.

\section{IGFR PATHWAY}

The IGF-I receptor (IGFR) signaling system consists of circulating ligands - IGF-I and IGF-II - interacting with a membrane receptor, such as type I IGF receptor (IGF-1R). The IGF-1R is a heterotetramer consisting of two extracellular ligand-binding $\alpha$ subunits and two $\beta$ subunits with transmembrane and TK domains (Figure 1). Upon ligand binding IGF-1R undergoes conformational changes and phosphorylation, leading to the recruitment of insulin-receptor substrates (IRS) and/or Src homology 2 domain-containing (Shc) proteins, with the consequential activation of pathways also common to EGFR, including the PI3K/Akt/mTOR-axis and the Ras/MEK/ERKpathway (Figure 2).

Constitutive activation of the IGF-signaling axis is frequently observed in a wide variety of tumors, including HCC $[95,96]$. The overexpression of IGF-II, IGF-1R, and IRS contributes to cell proliferation and the inhibition of apoptosis, as well as increasing invasive behavior in HCC [97]. In HCC the reactivation of IGF-signaling predominantly occurs at the level of IGF-II expression [98, 99], but not of IGF-I. Overexpression of IGF-II has been observed in 16-40\% of human HCC and around

Figure 3: A simplified overview of canonical Wnt signaling.
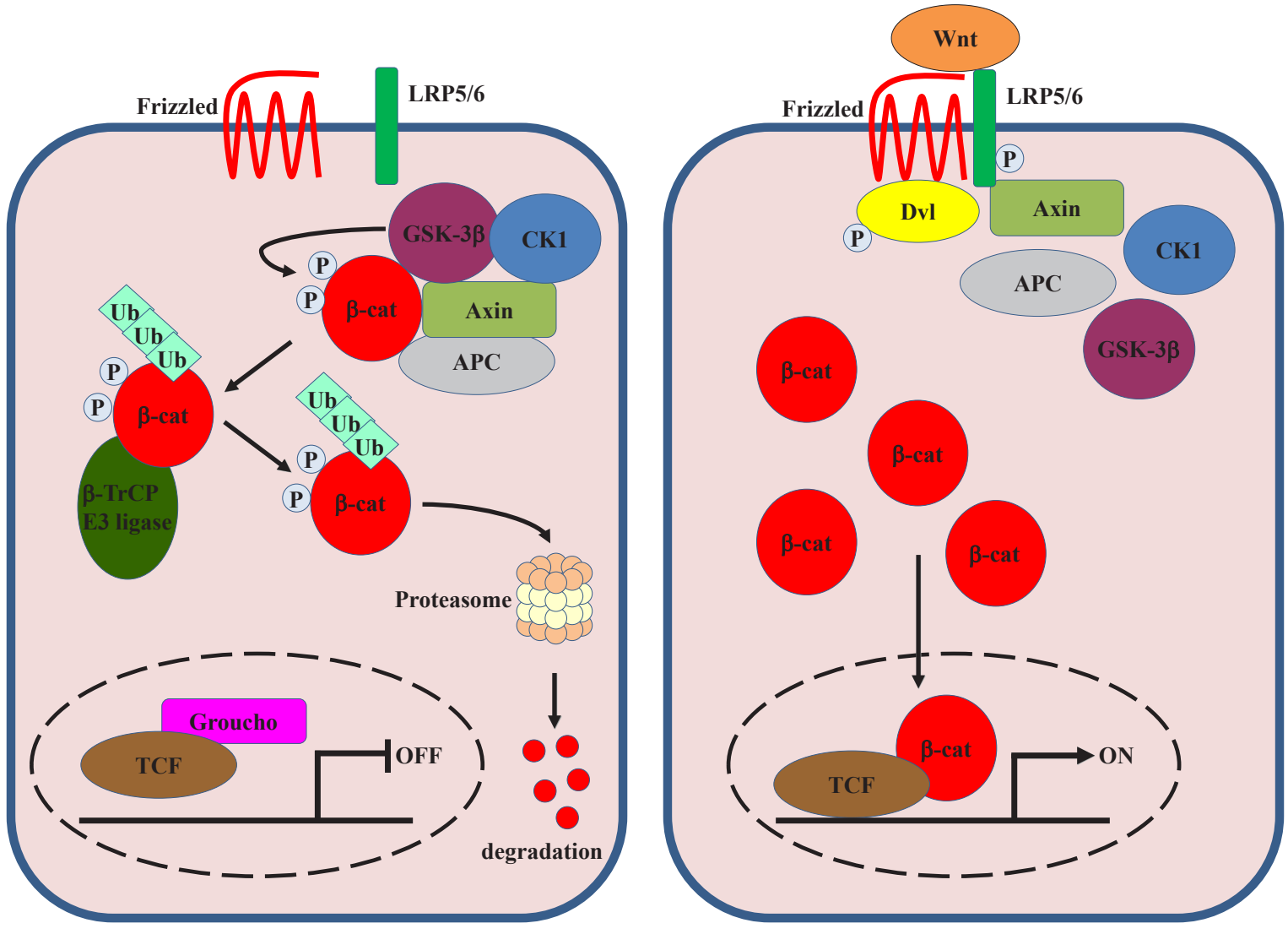
$30 \%$ of HCC cases overexpress IGF-1R [99, 100]. IGF-II overexpression is mainly due to altered methylation of the $I G F-2$ gene promoters P1-P4 [101]. Furthermore, in HBVand $\mathrm{HCV}$-associated $\mathrm{HCC}$, the $\mathrm{HBV}$-derived $\mathrm{HBx}$ protein and $\mathrm{HCV}$-derived core gene product have been reported to facilitate IGF-II overexpression [102, 103]. Moreover, in animal models of HCC the IGF signaling system also seems to be responsible for the development of HCC in obese and diabetic mice. Since obesity and diabetes are clearly associated with an increased risk of cancer in humans [104, 105], these observations highlighted the pivotal role of IGF signaling system in these patient categories.

\section{WNT/B-CATENIN PATHWAY}

The Wnt gene family encodes secreted glycoproteins involved in cell growth, differentiation, organogenesis, and oncogenesis. In a normal steady state (in the absence of Wnt proteins) $\beta$-catenin, the central player in the canonical Wnt pathway, is phosphorylated at aminoterminal serine and threonine residues by casein kinase 1 (CK1) and glycogen synthase kinase $3 \beta$ (GSK-3 $\beta$ ). $\beta$-catenin phosphorylation is facilitated by the scaffolding proteins axin and adenomatous polyposis coli (APC). Phosphorylated $\beta$-catenin is targeted for ubiquitination and protein degradation by the proteasome (Figure 3 ). Wnt signaling events are initiated by the binding of Wnt proteins to the seven-pass transmembrane Frizzled (FZD) receptor and the coreceptor low-density lipoproteinrelated protein (LRP) 5/6. Then, Dishevelled (Dvl) is recruited to the FZD receptor, and the FZD/Dvl complex subsequently relocates axin to LRP5/6. The recruitment of axin to LRP5/6 is mediated by phosphorylation of LRP5/6 on key residues by the kinases CK1 and GSK-3 $\beta$, which ultimately leads to GSK-3 $\beta$ inactivation. The absence of $\beta$-catenin phosphorylation releases it from the degradation complex composed of APC, axin, GSK-3 $\beta$ and CK1, resulting in an accumulation of $\beta$-catenin in the cytoplasm, since it cannot be degraded by the ubiquitin-proteasome pathway. As a consequence, $\beta$-catenin translocates into the nucleus where it binds to the lymphoid enhancer factor (LEF) or T-cell factor (TCF) transcriptional factors, displacing the transcriptional inhibitor Groucho, and in complex with LEF/TCF activates the expression of different genes which regulate cell proliferation and apoptosis (Figure 3).

A role for $\mathrm{Wnt} / \beta$-catenin signaling in $\mathrm{HCC}$ was discovered over a decade ago [106]. Activating mutations in the $\beta$-catenin gene (CTNNB1) were found in different human HCC cell lines and in HCC clinical samples in around $20 \%-40 \%$ of all cases [106-112]. These mutations impair the GSK-3 $\beta$-mediated phosphorylation of the protein at serine and threonine residues in its $\mathrm{N}$-terminus region. Intriguingly, $\mathrm{HCC}$ occurring in $\mathrm{HCV}$ patients showed a high incidence of $\beta$-catenin gene mutations (up to $40 \%$ of cases) $[109,113]$, whereas in HCC occurring in $\mathrm{HBV}$ patients $\beta$-catenin activation is induced in a mutation-independent manner by the expression of $\mathrm{HBx}$ protein $[114,115]$. However, in the absence of $\beta$-catenin gene mutations, aberrant activation of $\beta$-catenin has been identified in a significant subset of HCC patients with mutations in axin1/2 (5\%) [116]. The observation that expression of the wild-type AXIN1 gene by adenovirus mediated gene transfer induced apoptosis in HCC cells, which had accumulated $\beta$-catenin as a consequence of either $A P C, C T N N B 1$ or $A X I N 1$ gene mutation, highlights the fact that axin may be an effective therapeutic molecule for suppressing HCC growth [116]. Recently, since axin is the concentration-limiting component of the $\beta$-catenin destruction complex, stabilization of axin by inhibiting the poly-ADP-ribosylating enzymes tankyrase 1 and tankyrase 2 with small molecule inhibitor XAV939 has been presented as a new avenue for targeted Wnt/ $\beta$-catenin pathway therapies [117].

Moreover, accumulation of $\beta$-catenin in human HCC tumors containing the wild-type $\beta$-catenin gene has been observed in the context of up-regulation of the FZD7 receptor, which has been found up-regulated in $90 \%$ of human HCC [118-120], suggesting that FZD7 gene expression is the most common abnormality observed in HCC and consequently activation of Wnt/ Frizzled-mediated signaling plays a key role in liver carcinogenesis. Accordingly, Nambotin et al. demonstrated that pharmacological inhibition of FZD7 displayed anticancerous properties against HCC in vitro (on a panel of human HCC cell lines) and in vivo (on the SV40-TAg transgenic mouse model of HCC) [121]. Therefore, these observations suggest that the $\mathrm{Wnt} / \beta$-catenin signal transduction pathway is much more commonly involved in the molecular pathogenesis of $\mathrm{HCC}$ than previously recognized. Although no clinical studies are available, a preclinical study in which $\beta$-catenin suppression was achieved by antisense modalities has shown that $\beta$-catenin is essential for the survival and growth of hepatoma cells, independently of mutations in the $\beta$-catenin gene, and therefore this provides a proof of principle for the significance of the therapeutic inhibition of $\beta$-catenin in HCC [122].

\section{HEDGEHOG PATHWAY}

The Hedgehog (Hh) pathway is essential for embryonic development, tissue polarity and cell differentiation [123-125]. This pathway is critical in the early development of the liver and contributes to differentiation between hepatic and pancreatic tissue formation [126]. It remains inactive in healthy adult liver tissue, except during tissue regeneration and remodeling tissue repair, and Hh signaling may also play a role in primary liver cancers, such as cholangiocarcinoma and HCC $[127,128]$. The Hh signaling pathway is complex 
and requires two cellular receptors, Patched-1 (Ptch-1) receptor and Smoothened (Smo), a 7-transmembranous domains protein receptor. In the absence of ligand, Ptch1 represses Smo, thereby silencing the $\mathrm{Hh}$ signaling pathway. Binding of the Hh ligands - Sonic Hedgehog (Shh), Indian Hedgehog (Ihh) and Desert Hedgehog (Dhh) - to Ptch-1 liberates Smo from Ptch-1-mediated inhibition, thus initiating the propagation of an intracellular signaling cascade that leads to the activation and nuclear translocation of glioma-associated oncogene homologue (Gli) family transcription factors (Gli1, Gli2, Gli3) which regulate the expression of Gli-target genes [129]. The different Gli proteins show activating or repressing transcriptional activators depending on proteolytic cleavage of the full-length proteins. Gli1 and Gli2 mainly act as transcriptional activators, whereas in the absence or inhibition of Hh signaling processing of Gli3 produces a repressor form (Gli3R).

Hh has emerged as a critical mediator in the development of various diseases, including cancer, when aberrantly activated [130].

Although the study of Hh signaling in liver cells is in its infancy, some studies have shown that activation of the Hh pathway is involved in liver carcinogenesis [131-136]. Therefore, blockade of the Hh signaling pathway may be a potential new therapeutic strategy in HCC.

The relevance of blocking the Hh pathway for HCC treatment can be further supported by the evidence that this pathway can cross-talk with the Wnt/ $\beta$-catenin signaling pathway, a well-known oncogenic pathway implicated in HCC development $[137,138]$. Taken together, these data suggest that inhibition of the $\mathrm{Hh}$ pathway may provide a useful therapeutic option for the treatment of HCC.

\section{INFLAMMATORY PATHWAY (IL-6/STAT3, TNF- $\alpha$, NF-KB, COX-2)}

The link between inflammation and cancer was first suggested by Rudolph Virchow in 1863, and is now a widely-accepted paradigm of carcinogenesis [139, 140]. Nowadays epidemiological data have undoubtedly demonstrated a clear association between chronic inflammation and tumor development, including HCC [141-143]. Although the molecular mechanisms by which chronic inflammation increases the risk of HCC are not completely known, compelling evidence gathered over the past few years has demonstrated the roles of inflammatory factors, such as IL-6, cyclooxygenase 2 (COX-2)/ prostaglandin $\mathrm{E}_{2}\left(\mathrm{PGE}_{2}\right)$ and tumor necrosis factor $\alpha$ (TNF- $\alpha$ ) in HCC development [142].

IL-6 mediates its diverse biological effects by interacting with a receptor complex consisting of a specific ligand-binding protein (IL-6R, gp80) and a signal transduction protein (gp130) and regulates the JAK/STAT3, Ras/MAP kinase and PI3K/Akt pathways. A key feature in our understanding of the regulation of
IL-6 responses has been the identification of a soluble form of the IL-6 receptor (sIL-6R) [144]. When the IL-6/sIL-6R complex associates with the membranebound signal-transducing chain, it can induce the signal transduction cascade, acting as an agonist and stimulating a variety of cellular responses including the proliferation, differentiation and activation of inflammatory processes.

A large body of evidence has been accumulating in recent years which indicates that IL-6 is involved in liver carcinogenesis [143, 145]. In this line, Michael Karin's group showed that IL-6 participates in hepatocarcinogenesis, using diethylnitrosamine (DEN)induced murine HCC models [146]. They also showed that estrogen-mediated inhibition of IL-6 production by Kupffer cells reduces liver cancer risk in females and these findings not only may be used to prevent HCC in males, but also may be a possible clue for the enigma of gender difference in HCC occurrence found in epidemiologic data [147]. Recently, a retrospective cohort study was conducted to examine whether the results observed in the mouse models were applicable to human HCC [148]. No significant difference in serum IL-6 levels was found between female and male chronic hepatitis $\mathrm{C}$ patients. Unexpectedly, in a multivariate analysis higher serum IL-6 level was an independent risk factor for HCC development in female but not in male chronic hepatitis $\mathrm{C}$ patients. Therefore, the gender disparity in liver carcinogenesis in humans cannot be attributed solely to the difference in IL-6 levels. Interestingly, a recent report suggested that Foxa factors (Foxa 1 and Foxa2) and their targets are central for the sexual dimorphism of HCC [149]. The mechanism of gender disparity remains to be further investigated.

Nevertheless, many works have reported high serum levels of IL-6 in various liver diseases, including HCC. Serum IL-6 levels are significantly higher in patients with HCC than in healthy individuals [150-152] and higher levels of IL-6 have been correlated with tumor mass and cancer invasiveness $[150,153]$. Moreover, IL-6 is much higher in stage III HCC patients than in stage I and II patients [151]. As regards sIL-6R, although no significant difference in sIL-6R levels were observed between control subjects and patients with HCC, sIL-6R levels resulted higher in patients with a more advanced stage of disease [151, 154].

STAT3 is the major mediator of IL-6 and growth factor (e.g. EGF, PDGF and HGF) signaling, transmitting signals from the cell membrane to the nucleus. STAT3 activation requires phosphorylation of a critical tyrosine residue (Tyr705), which mediates its dimerization, which is a prerequisite for nucleus entry and DNA binding. The phosphorylation of STAT3 at Tyr705 is most commonly mediated by Janus kinases (JAKs), especially JAK2. Activated STAT3 can mediate oncogenic transformation in cultured cells and promote tumor formation in nude mice, thus qualifying STAT3 as a proto-oncogene [155]. 
STAT3 is constitutively activated in human HCC tissues, but not in adjacent non-tumor liver parenchyma or normal liver tissue $[156,157]$. A recent report demonstrated that the STAT3 signaling pathway is very complex and may participate in HCC genesis and development by regulating the protein expression of other signaling pathways, telomerase, apoptosis, the cell cycle and angiogenesis [158]. Targeting STAT3 as a potential cancer therapy has been extensively investigated [159], and recently new small-molecule inhibitors have been developed which show to inhibit IL-6-induced STAT3 activation and nuclear translocation in HCC cells [160]. Therefore, targeting IL-6/STAT3 seems to be a promising strategy for HCC therapy.

An inducible enzyme with carcinogenic properties that is active within inflamed and malignant tissues is cyclooxygenase-2 (COX-2). The COX enzymes (COX-1 and COX-2) are well-known targets of non-steroidal antiinflammatory drugs (NSAIDs). Many epidemiological studies have demonstrated that treatment with NSAIDs reduces the incidence and mortality of certain malignancies, especially gastrointestinal cancer [161]. However, conventional NSAIDs non-selectively inhibit both the constitutive form COX-1, and the inducible form COX-2. Recent evidence indicates that COX-2 is an important molecular target for anticancer therapies. Its expression is undetectable in most normal tissues, and is highly induced by pro-inflammatory cytokines, mitogens, tumor promoters and growth factors. It is now well-established that COX-2 is chronically overexpressed in many premalignant, malignant, and metastatic cancers [162], including HCC [163-165]. Overexpression of COX-2 in patients with HCC is generally higher in welldifferentiated HCCs compared with less-differentiated HCCs or histologically normal liver, suggesting that COX-2 may be involved in the early stages of liver carcinogenesis [163-165] and increased expression of COX-2 in noncancerous liver tissue has been significantly associated with postoperative recurrence and shorter disease-free survival in patients with $\operatorname{HCC}[166,167]$. In tumors, overexpression of COX-2 leads to an increase in prostaglandin levels, which affect many mechanisms involved in carcinogenesis, such as angiogenesis, inhibition of apoptosis, stimulation of cell growth as well as the invasiveness and metastatic potential of tumor cells [168].

The availability of novel agents that selectively inhibit COX-2 (COXIB) has contributed to shed light on the role of this molecule. Experimental studies on animal models of HCC have shown that NSAIDs, including both selective and non-selective COX-2 inhibitors, exert chemopreventive as well as therapeutic effects [169-172]. However, the key mechanism by which COX-2 inhibitors affect HCC cell growth is as yet not fully understood. Increasing evidence suggests the involvement of molecular targets other than COX-2 in the anti-proliferative effects of
COX-2 selective inhibitors, including the MAPK cascade [173, 174], PI3K/Akt pathway [175] and its upstream kinase PDK-1 [176], the anti-apoptotic proteins survivin, Bcl-2 and Mcl-1 [177, 178], cyclin-dependent kinase inhibitors and cyclins [179], as well as the sacroplasmic/ endoplasmic reticulum calcium ATPase SERCA [180]. Interestingly, COX-2-independent effects of celecoxib have also been observed during liver carcinogenesis in vivo. In the study by Marquez-Rosado [169] neither COX-2 expression nor $\mathrm{PGE}_{2}$ production were altered by celecoxib treatment, suggesting that celecoxib effects are mediated by $\mathrm{COX}-2 / \mathrm{PGE}_{2}$-independent mechanisms.

Therefore, COX-inhibitors may use both COX2-dependent and COX-2-independent mechanisms to mediate their antitumor properties [174, 181, 182], although their relative contributions toward the in vivo effects remain less clear.

Interestingly, celecoxib also inhibits IL-6/IL-6 receptor-induced JAK2/STAT3 phosphorylation in human HCC cells [183].

The NF- $\kappa \mathrm{B}$ pathway has also been recognized as an underlying link between inflammation and malignancy [184]. The transcription factor NF- $\kappa \mathrm{B}$ is a ubiquitous transcription factor present in all cell types. In unstimulated cells, NF- $\kappa \mathrm{B}$ resides in the cytoplasm as a heterotrimer consisting of p50, p65, and $\mathrm{I} \kappa \mathrm{B} \alpha$. The binding of a ligand, such as cytokines or lipopolysaccharide (LPS), to a receptor leads to the recruitment and activation of an IкB kinase (IKK) complex, which consists of IKK $\alpha$ and/or IKK $\beta$ catalytic subunits and two molecules of NEMO. Phosphorylation of serine residues of IкB by IKK leads to I $\mathrm{B}$ ubiquitination and subsequent proteosomal degradation. p50 and p65 are then released and translocated into the nucleus, where gene expression is activated. Most genes linked with tumorigenesis are regulated by $\mathrm{NF}-\kappa \mathrm{B}$, such as those mediating inflammation, cell survival, cell proliferation, invasion, angiogenesis, and metastasis.

In recent years, several results have established strong support for the critical role of $\mathrm{NF}-\kappa \mathrm{B}$ in many types of cancer, including $\mathrm{HCC}[185,186]$. NF- $\kappa \mathrm{B}$ is aberrantly expressed and activated in both human $\mathrm{HCC}$ tissue and HCC cells [187-189]. Several preclinical

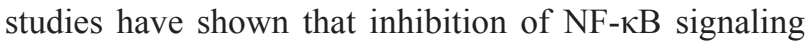
by pharmacological or genetic approaches [189-192] results in an antitumor effect in $\mathrm{HCC}$, suggesting that $\mathrm{NF}-\kappa \mathrm{B}$ is a potential molecular target for HCC therapy. Worthy of note is the observation that celecoxib potently inhibits the nuclear translocation and activation of NF$\kappa \mathrm{B}$ by $\mathrm{COX}-2$-dependent and -independent mechanisms [169, 181, 193, 194]. Interestingly, we recently reported that combination of celecoxib with the novel NF- $\kappa B$ inhibitor dehydroxymethyl-epoxyquinomicin (DHMEQ)

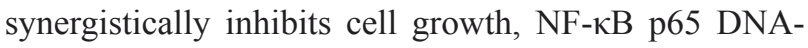
binding capacity, and cell proliferation in human $\mathrm{HCC}$ cells [195], providing a rational basis for the clinical use 
of this combination in the treatment of liver cancer.

The important role of inflammatory pathways in liver carcinogenesis is further reinforced by recent studies by Michael Karin's team, published in Cell in 2010 [196]. Park et al. demonstrated that either dietary or genetic obesity is a potent bona fide liver tumor promoter in mice. Obesity-promoted HCC development was dependent on the production of the tumor-promoting cytokines IL- 6 and TNF- $\alpha$, which cause hepatic inflammation and activation of the oncogenic transcription factor STAT3. The chronic inflammatory response caused by obesity and enhanced production of IL- 6 and TNF- $\alpha$ ma also increase the risk not only of HCC but of other cancers $[105,196]$.

\section{OTHER POTENTIAL THERAPEUTIC TARGETS IN HCC}

As stated above, during the multistep biological process involved in the development of HCC several genetic and epigenetic alterations occur and various pathways are involved, including transforming growth factor (TGF)- $\beta$ [197], hepatocyte growth factor (HGF)/ c-MET [198-200], Hyppo [201] and Notch [202, 203] signaling. These molecules may represent critical therapeutic targets for HCC intervention as well as for other cancers.

\section{MOLECULAR-TARGETED THERAPY IN $\mathrm{HCC}$}

Several recent reviews have been published describing in detail the results of clinical trials of molecular-targeted agents for the treatment of HCC [204208]. Here, we briefly review only some of them, whereas an updated list of data accessed up to February 2012 by searching the clinicaltrials.gov website on ongoing clinical trials in HCC patients is reported (Table 1).

\section{TARGETING THE RAF/MEK/ERK PATHWAY}

The Raf kinase inhibitor sorafenib (Nexavar, BAY43-9006) is currently the most promising molecular targeting drug for HCC. Sorafenib, is a multikinase inhibitor, which in addition to targeting Raf kinases also inhibits VEGFR-2/-3, PDGFR- $\beta$, Flt-3 and c-Kit $[42,209,210]$ (Figure 1). On the basis of the recent large randomized phase III study, the Sorafenib HCC Assessment Randomized Protocol (SHARP), Sorafenib has been approved by the United States (US) Food and Drug Administration (FDA) for the treatment of patients with advanced HCC [211]. In the SHARP trial median overall survival (OS) increased from 7.9 months in the placebo group to 10.7 months in the sorafenib group. Sorafenib showed a significant benefit also in terms of time to progression (TTP), with a median of 5.5 months in the sorafenib group and 2.8 months in the placebo group. On the basis of these findings, the FDA, European Medicine Agency (EMA) and other regulatory authorities in the world have approved sorafenib for advanced HCC treatment. However, although sorafenib is well tolerated, concern for its safety has been expressed. Most common adverse events reported in the SHARP trial were diarrhea and hand-foot skin reactions [211]. Sorafenib is currently undergoing investigation in a phase III study - the STORM trial - in HCC patients as an adjuvant therapy for the prevention of recurrence following surgery or local ablation (http://clinicaltrials.gov/ct2/show/ NCT00692770).

In addition to sorafenib other molecular targeting agents have been used in clinical trials for advanced HCC treatment (Table 1). However, most of them have demonstrated very low responses. The low response rate associated with monotherapy indicates the need to explore combinations of different molecular targeting agents, but also combinations of a single agent with conventional cytotoxic drugs. In this context, a phase II trial demonstrated that the addition of sorafenib to doxorubicin improves progression-free and overall survival of patients with advanced HCC [212]. Moreover, a phase II trial is currently recruiting patients to determine the progression-free survival of sorafenib plus tegafur/ uracil (UFUR) for the treatment of advanced or metastatic HCC (NCT00464919).

In addition to Raf inhibition, preclinical studies have demonstrated the potential of MEK inhibition to suppress hepatoma cell proliferation and tumorigenicity [44, 46, 213-216]. Huynh et al. recently reported that treatment of human HCC xenografts with AZD6244 (ARRY-142886, Selumetinib), a selective MEK inhibitor, blocked ERK1/2 activation, reduced in vivo tumor growth and induced apoptosis [44]. Targeting MEK with the selective MEK inhibitor PD0325901, a derivative of CI-1040, had in vivo chemopreventive effects on HCC development in an animal model employing TGF- $\alpha$-transgenic mice with liver cancers induced by diethylnitrosamine treatment [217]. In addition, a combination of the MEK inhibitor AZD6244 and the conventional cytostatic drug doxorubicin enhanced the antineoplastic activity of the respective monotherapeutic HCC treatment with doxorubicin alone [218]. MEK inhibitors have also been shown to potentiate the antitumor activity of selective COX-1 and COX-2 inhibitors in suppressing growth and inducing apoptosis in human liver cancer cells [174].

Taken together, the in vitro and preclinical in vivo data show that MEK inhibitors are promising agents for HCC treatment. However, a multicenter phase II clinical study failed to demonstrate a clinical benefit for AZD6244 as a single agent in patients with advanced HCC [219]. This result suggests that inhibition of MEK signaling alone is not sufficient to successfully treat advanced-stage 
HCC, therefore two clinical trials are currently testing AZD6244 in HCC patients with less severe disease, i.e. moderate liver dysfunction, and also in association with sorafenib (Table 1).

\section{TARGETING THE PI3K/AKT/MTOR PATHWAY}

The PI3K/Akt/mTOR pathway appears to be one of the major contributors to the development and maintenance of HCC. Although some preclinical studies have demonstrated that PI3K inhibitors such as perifosine, LY29004 and wortmannin have anti-HCC activity, no studies have been conducted so far at the clinical level.

A phase II Study of MK-2206 (a novel oral potent allosteric Akt inhibitor) in advanced HCC patients who have not responded or are intolerant to one previous line of anti-angiogenic therapy is currently recruiting patients (NCT01239355). Of interest, a recent study showed that the combination of sorafenib and MK-2206 overcomes the resistance of HCC cells to sorafenib at clinically achievable concentrations, suggesting the potential use of this treatment in HCC patients [220].

Evidence from in vitro experiments, as well as from preclinical in vivo data, indicated that mTOR inhibition by rapamycin and its analogues everolimus (RAD001) significantly reduced the growth of HCC cells and improved survival primarily via antiangiogenic effects [221-224].

A pilot study conducted on 21 patients with advanced HCC indicated that sirolimus (rapamycin) was a promising drug for the treatment of $\mathrm{HCC}$ and a randomized phase I/II trial evaluating the rapamycin analog RAD001 (everolimus) for advanced HCC is currently recruiting patients (http://clinicaltrials.gov/ct2/show/NCT00516165).

Other clinical trials are ongoing to evaluate dose limited toxicity and efficacy in advanced HCC patients treated with the mTOR inhibitor Torisel (temsirolimus). Furthermore, a phase I/II multicentre study to assess the safety, tolerability, pharmacokinetics and preliminary efficacy of AZD8055, a novel ATP-competitive inhibitor of mTOR kinase, is recruiting Asian patients with advanced stage HCC (Table 1).

A topic of considerable current interest concerns the signal transduction pathways and molecular mechanisms linked to the chemoresistance of tumor cells to conventional anticancer drugs. In this context, a combination of rapamycin with the conventional cytostatic drugs doxorubicin and vinblastine enhances the antineoplastic activity of the respective monotherapeutic HCC treatment with either doxorubicin or vinblastine alone $[225,226]$.

In addition to studies on the combination of mTOR inhibitors with conventional chemotherapeutic agents, two phase I/II clinical studies are currently recruiting patients with advanced HCC to determine the safety/toxicity profile of temsirolimus in combination with sorafenib (Table 1).

Taken together, the in vitro and preclinical in vivo data, as well as the clinical trials, conducted so far demonstrate that mTOR inhibitors are promising agents for HCC treatment, particularly in combination with conventional chemotherapeutic drug therapy.

\section{TARGETING THE VEGF/VEGFR, FGF/ FGFR AND PDGF/PDGFR PATHWAYS}

HCC is a hypervascular tumor mainly supplied by the hepatic arteries and secretion by HCC cells, tumorinfiltrating inflammatory cells and hepatic stellate cells of factors such as VEGF, bFGF, angiopoietins, PDGF and others promotes the sprouting of new vessels from nearby existing vessels.

VEGF, is one of the strongest stimulatory angiogenic factors, and is up-regulated in most human tumors, including HCC [227, 228]. In a recent systemic review and meta-analysis study, the prognostic role of VEGF as a predictor of survival in patients with treated $\mathrm{HCC}$ was established [229]. High tissue VEGF levels predicted poor overall ( $\mathrm{HR}=2.15,95 \% \mathrm{CI}: 1.26-3.68)$ and disease-free (HR $=1.69,95 \%$ CI: $1.23-2.33)$ survival. Similarly, high serum VEGF levels predicted poor overall ( $\mathrm{HR}=2.35,95 \%$ CI: $1.80-3.07)$ and disease-free (HR=2.36, 95\% CI 1.76 3.16) survival. Therefore, the inhibition of angiogenesis may represent a potential therapeutic target in HCC, and many antiangiogenic agents are under evaluation in clinical trials in HCC.

Bevacizumab is a recombinant humanized monoclonal antibody against VEGF which has been used either as a single agent or in combination with cytotoxic or other targeted agents in several clinical studies already concluded in patients with advanced HCC [230-236], whereas others are still recruiting patients (Table 1). Overall, the concluded studies demonstrated that although bevacizumab is a well-tolerated agent, the side effects associated with its administration, including bleeding, hypertension, proteinuria, and thromboembolic events, warrant further evaluation.

Other multiple RTK inhibitors that target VEGF are under investigation, including brivanib, linifanib (formerly ABT-869), vandetanib, and pazopanib.

Recently, in a phase II trial brivanib, a selective dual inhibitor of VEGF and FGF signaling, was evaluated as a first-line therapy in patients with unresectable, locally advanced or metastatic hepatocellular carcinoma. The study showed a median OS of 10 months. Brivanib was generally well tolerated; the most common adverse effects included fatigue, hypertension, and diarrhea [237]. Based on these results a randomized, double-blind, multi-center phase III study of brivanib versus sorafenib as first-line treatment is currently testing the OS of patients with advanced $\mathrm{HCC}$ who have not received prior systemic 
therapy (NCT00858871), whereas another phase III trial, the BRISK PS Study (Brivanib Study in HCC Patients at Risk Post Sorafenib), is evaluating brivanib plus best supportive care (BSC) versus placebo plus BSC in subjects with advanced HCC who have not responded or are intolerant to sorafenib (NCT00825955).

Linifanib (ABT-869) is a novel orally active, potent and selective inhibitor of the VEGF and PDGF receptor tyrosine kinases. A phase II study on 44 patients with advanced HCC showed a response rate of $7 \%$, a median PFS of 3.7 months and median survival of 9.3 months [238]. This study concluded that linifanib is clinically active in advanced HCC, with an acceptable safety profile. On the basis of these results, a phase III study of linifanib versus sorafenib is ongoing.

A phase II, placebo-controlled study of vandetanib (ZD6474), which targets VEGFR, EGFR and RET signaling, showed activity in patients with inoperable HCC but failed to meet its primary aim of tumor stabilization [239]. However, the PFS and OS results suggest that vandetanib has clinical activity in this patient population that may warrant further investigation.

Finally, a report from a phase I dose-ranging study of pazopanib (GW786034), an oral inhibitor targeting VEGF, PDGF and c-kit, showed evidence of antitumor activity [240].

\section{TARGETING THE EGFR PATHWAY}

Another promising target in $\mathrm{HCC}$ is the EGFR pathway. As mentioned above, EGFR and its ligand EGF play an important role in hepatocarcinogenesis. Two therapeutic approaches are currently being employed in clinical trials in HCC patients, by using either a monoclonal antibody neutralizing the EGFR (cetuximab) or three small-molecule tyrosine kinase inhibitors of the EGFR (erlotinib, gefinitib and lapatinb). Overall, the results have been disappointing. Indeed, in phase II clinical trials in which erlotinib, gefitinib, lapatinib and cetuximab were assessed in patients with advanced HCC response rates $(\mathrm{RR})$ varied in the range of $0 \%-9 \%$, the median PFS time reported was approximately 1.4-3.2 months and OS ranged 6.2-13 months [241-244]. Consequently, several ongoing clinical trials are combining EGFR inhibitors with another therapeutic modality such as cytotoxic drugs and other molecular-targeted agents [235, 236, 245, 246] (Table 1).

\section{TARGETING THE IGF PATHWAY}

Constitutive activation of the IGF-signaling axis is frequently observed in HCC $[95,96]$. In HCC the activation of IGF-signaling has antiapoptotic and growthpromoting effects and acts through multiple signaling cascades, including the PI3K/Akt and MAPK pathways. As for other pathways, small molecules (such as OSI-
906) and monoclonal antibodies (such as IMC-A12 and AVE-1642) targeting IGF signaling are under evaluation in clinical trials in HCC patients (Figure 1 and Table 1).

Pre-clinical evidence obtained in vitro in $\mathrm{HCC}$ cells showed that IMC-A12 decreased cell viability and proliferation and blocked ligand-induced IGF$1 \mathrm{R}$ activation. In vivo A12 delayed tumor growth and prolonged survival, reducing proliferation rates and inducing apoptosis [247]. Therefore, these data suggest that IMC-A12 effectively blocks IGF signaling, thus providing the rationale for testing this therapy in clinical trials. Indeed, an initial phase I study of IMC-A12 (cituxumumab) yielded a partial response in HCC [248], however a subsequent phase II study in patients with advanced HCC showed that IMC-A12 is inactive as a monotherapy in HCC [249].

AVE1642 is a humanized monoclonal antibody that specifically blocks IGF-1R signaling. A phase I study showed that AVE1642 can be safely combined with active doses of sorafenib, and the pharmacokinetics of both AVE1642 and sorafenib were not modified at the concentrations tested. Interestingly, long-lasting disease stabilizations were observed in most patients with progressive disease [250].

Recently, OSI-906, a novel orally-efficacious small-molecule dual IGF-1R/Insulin receptor (IR) kinase inhibitor has been isolated and is being evaluated as a therapeutic agent for HCC [251]. OSI-906 is currently being tested in a randomized, placebo-controlled, doubleblinded phase 2 study of second-line treatment in patients with advanced HCC after failure of first-line treatment with sorafenib (NCT01101906; Table 1).

\section{CONCLUSIONS}

The recent identification of several key molecular pathways implicated in the pathogenesis of HCC has led to the development of new targeted therapies for this devastating disease. Targeting the various effectors of these pathways with pharmacologic inhibitors may inhibit HCC cell growth and angiogenesis. Several promising novel anticancer agents are currently under investigation for the treatment of HCC. Ongoing clinical trials are offering hope to improve the progression-free survival of patients with advanced HCC.

The specific action of the new molecular-targeted agents minimizes the toxicity typical of systemic chemotherapy, although attention needs to be paid to the onset and management of side effects related to treatment with these new agents.

Combination therapy with either conventional cytotoxic drugs or another inhibitor which targets a specific molecule in a different signal transduction pathway is also a key approach for improving the effectiveness and usefulness of new molecular-targeted agents. This avenue of investigation has not been pursued 
as rigorously as it could be, often due to the conflicting interests of the pharmaceutical companies, since different companies will often have competing interests for the different inhibitors/chemotherapeutic drugs. Nevertheless, the field of molecular-targeted therapy in cancer therapy has already come a long way. It is not hard to see an even brighter future on the horizon. However, many additional clinical trials, as well as the development of novel, innovative approaches to cure or suppress the further development of HCC need to be performed and developed to improve therapy in $\mathrm{HCC}$ patients.

\section{ACKNOWLEDGEMENTS}

MC and GM have been supported in part by grants PRIN 2008 and FIRB-MERIT n. RBNE08YYBM from the Italian Ministry for Education, the University and Research - MIUR. MC has been also supported in part by a grant to the CNR from the Italian Ministry of Economy and Finance for the Project FaReBio di Qualità.

\section{REFERENCES}

1. Montalto G, Cervello M, Giannitrapani L, D'Antona F, Terranova A, Castagnetta LM. Epidemiology, risk factors and natural history of hepatocellular carcinoma. Ann N Y Acad Sci. 2002; 963: 13-20.

2. Llovet JM, Burroughs A, Bruix J. Hepatocellular carcinoma. Lancet. 2003; 362: 1907-1917.

3. Parkin DM, Whelan SL, Ferlay J, L Teppo, Thomas DB (eds.) Cancer Incidence In Five Continents. Vol. VIII IARC, Scientific Publications No 155. Lyon 2002; 1-782.

4. Schütte K, Bornschein J, Malfertheiner P. Hepatocellular carcinoma--epidemiological trends and risk factors. Dig Dis. 2009; 27: 80-92.

5. Chang MH, Chen CJ, Lai MS, Hsu HM, Wu TC, Kong MS, Liang DC, Shau WY, Chen DS. Universal hepatitis B vaccination in Taiwan and the incidence of hepatocellular carcinoma in children. N Engl J Med. 1997; 336: 18551859 .

6. Yu SZ. Primary prevention of hepatocellular carcinoma. J Gastroenterol Hepatol. 1995; 10: 674-682.

7. McGlynn KA, Tsao L, Hsing AW, Devesa SS, Fraumeni JF. International trends and patterns of primary liver cancer. Int J Cancer. 2001; 94: 290-296.

8. Schwartz M, Roayaie S, Konstadoulakis M. Strategies for the management of hepatocellular carcinoma. Nat Clin Pract Oncol. 2007; 4: 424-432.

9. El-Serag HB, Rudolph L. Hepatocellular carcinoma: epidemiology and molecular carcinogenesis. Gastroenterology. 2007; 132: 2557-2576.

10. Shimada M, Hashimoto E, Taniai M Hasegawa K, Okuda H, Hayashi N, Takasaki K, Ludwig J. Hepatocellular carcinoma in patients with non-alcoholic steatohepatitis. J
Hepatol. 2002; 37: 154-160.

11. Adams LA, Lymp JF, St Sauver J, Sanderson SO, Lindor KD, Feldstein A, Angulo P. The natural history of nonalcoholic fatty liver disease: a population-based cohort study. Gastroenterology. 2005; 129: 113-121.

12. Marrero JA, Fontana RJ, Su GL, Conjeevaram HS, Emick DM, Lock AS. NAFLD may be a common underlying liver disease in patients with hepatocellular carcinoma in the United States. Hepatology. 2002; 36: 1349-1354.

13. Larsson SC, Wolk A. Overweight obesity and risk of liver cancer: a meta-analysis of cohort studies. Br J Cancer. 2007; 97: 1005-1008.

14. Cook MB, Dawsey SM, Freedman N, Inskip PD, Wichner SM, Quraishi SM, Devesa SS, McGlynn KA. Sex disparities in cancer incidence by period age. Cancer Epidemiol Biomarkers Prev. 2009; 18: 1174-1182.

15. Di Maio M, De Maio E, Morabito A, D’Aniello R, De Feo G, Gallo C, Perrone F. Hormonal treatment of human hepatocellular carcinoma. Ann N Y Acad Sci. 2006; 1089: 252-261.

16. Llovet JM, Bruix J. Molecular targeted therapies in hepatocellular carcinoma. Hepatology. 2008; 48: 13121327.

17. McCubrey JA, Steelman LS, Kempf CR, Chappell W, Abrams SL, Stivala F, Malaponte G, Nicoletti F, Libra M, Bäsecke J, Maksimovic-Ivanic D, Mijatovic S, Montalto G, Cervello M, Cocco L, Martelli AM. Therapeutic Resistance Resulting from Mutations in Raf/MEK/ERK and PI3K/ PTEN/Akt/mTOR Signaling Pathways. J Cell Physiol. 2011; 226: 2762-2781.

18. Ligresti G, Militello L, Steelman LS, Cavallaro A, Basile F, Nicoletti F, Stivala F, McCubrey JA, Libra M. PIK3CA mutations in human solid tumors: role in sensitivity to various therapeutic approaches. Cell Cycle. 2009; 8: 13521358.

19. Demidenko ZN, McCubrey JA. Recent progress in targeting cancer. Aging (Albany NY). 2011; 3: 1154-1162.

20. McCubrey JA, Steelman LS, Abrams SL, Chappell WH, Russo S, Ove R, Milella M, Tafuri A, Lunghi P, Bonati A, Stivala F, Nicoletti F, Libra M, Martelli AM, Montalto G, Cervello M. Emerging Raf inhibitors. Exp Opin Emerging Drugs. 2009; 14: 633-648.

21. McCubrey JA, Steelman LS, Abrams SL, Chappell WH, Russo S, Ove R, Milella M, Tafuri A, Lunghi P, Bonati A, Stivala F, Nicoletti F, Libra M, Martelli AM, Montalto G, Cervello M. Emerging MEK inhibitors. Expert Opin Emerg Drugs. 2010; 15: 203-223.

22. Higgins MJ, Baselga J. Targeted therapies for breast cancer. J Clin Invest. 2011; 121: 3797-3803.

23. Vaccaro V, Melisi D, Bria E, Cuppone F, Ciuffreda L, Pino MS, Gelibter A, Tortora G, Cognetti F, Milella M. Emerging pathways and future targets for the molecular therapy of pancreatic cancer. Expert Opin Ther Targets. 2011; 15: 1183-1196. 
24. Markman B, Dienstmann R, Tabernero J. Targeting the $\mathrm{PI} 3 \mathrm{~K} / \mathrm{Akt} / \mathrm{mTOR}$ pathway--beyond rapalogs. Oncotarget. 2010; 1: 530-543.

25. Curtin JC, Lorenzi MV. Drug discovery approaches to target Wnt signaling in cancer stem cells. Oncotarget. 2010; 1: 563-577.

26. Harada K, Shiota G, Kawasaki H. Transforming growth factor-alpha and epidermal growth factor receptor in chronic liver disease and hepatocellular carcinoma. Liver. 1999; 19: 318-325.

27. Hisaka T, Yano H, Haramaki M, Utsunomiya I, Kojiro M. Expressions of epidermal growth factor family and its receptor in hepatocellular carcinoma cell lines: relationship to cell proliferation. Int J Oncol. 1999; 14: 453-460.

28. Ito $\mathrm{Y}$, Takeda $\mathrm{T}$, Sakon M, Tsujimoto M, Higashiyama S, Noda K, Miyoshi E, Monden M, Matsuura N. Expression and clinical significance of erb-B receptor family in hepatocellular carcinoma. Br J Cancer. 2001; 84: 1377 1383.

29. Kannangai R, Sahin F, Torbenson MS. EGFR is phosphorylated at Ty845 in hepatocellular carcinoma. Mod Pathol. 2006; 19: 1456-1461.

30. Kira S, Nakanishi T, Suemori S, Kitamoto M, Watanabe Y, Kajiyama G. Expression of transforming growth factor alpha and epidermal growth factor receptor in human hepatocellular carcinoma. Liver. 1997; 17: 177-182.

31. Foster J, Black J, LeVea C, Khoury T, Kuvshinoff B, Javle $\mathrm{M}$, Gibbs JF. COX-2 expression in hepatocellular carcinoma is an initiation event; while EGF receptor expression with downstream pathway activation is a prognostic predictor of survival. Ann Surg Oncol. 2007; 14: 752-758.

32. Tanabe KK, Lemoine A, Finkelstein DM, Kawasaki H, Fujii T, Chung RT, Lauwers GY, Kulu Y, Muzikansky A, Kuruppu D, Lanuti M, Goodwin JM, Azoulay D, Fuchs BC. Epidermal growth factor gene functional polymorphism and the risk of hepatocellular carcinoma in patients with cirrhosis. JAMA. 2008; 299: 53-60.

33. Abu Dayyeh BK, Yang M, Fuchs BC, Karl DL, Yamada S, Sninsky JJ, O'Brien TR, Dienstag JL, Tanabe KK, Chung RT; HALT-C Trial Group. A Functional polymorphism in the epidermal growth factor gene is associated with risk for hepatocellular carcinoma. Gastroenterology. 2011; 141: 141-149.

34. Minden A, Lin A, McMahon M, Lange-Carter C, Dérijard B, Davis RJ, Johnson GL, Karin M. Differential activation of ERK and JNK mitogen-activated protein kinases by Raf1 and MEKK. Science. 1994; 266: 1719-1723.

35. Lange-Carter CA, Johnson GL. Ras-dependent growth factor regulation of MEK kinase in PC12 cells. Science. 1994; 265: 1458-1461.

36. Marais R, Light Y, Paterson HF and Marshall CJ. Ras recruits Raf-1 to the plasma membrane for activation by tyrosine phosphorylation. EMBO J. 1995; 14: 3136-3145.

37. Xu S, Robbins D, Frost J, Dang A, Lange-Carter C, Cobb
MH. MEKK1 phosphorylates MEK1 and MEK2 but does not cause activation of mitogen-activated protein kinase. Proc Natl Acad Sci USA. 1995; 92: 6808-6812.

38. Deng T, Karin M. c-Fos transcriptional activity stimulated by H-Ras-activated protein kinase distinct from JNK and ERK. Nature. 1994; 371: 171-175.

39. Xing J, Ginty DD, Greenberg ME. Coupling of the RASMAPK pathway to gene activation by RSK2, a growth factor-regulated CREB kinase. Science. 1996; 273: 959963.

40. Davis RJ. Transcriptional regulation by MAP kinases. Mol Reprod Dev. 1995; 42: 459-467.

41. Steelman LS, Chappell WH, Abrams SL, Kempf RC, Long J, Laidler P, Mijatovic S, Maksimovic-Ivanic D, Stivala F, Mazzarino MC, Donia M, Fagone P, Malaponte G, Nicoletti F, Libra M, Milella M, et al. Roles of the Raf/MEK/ERK and PI3K/PTEN/Akt/mTOR pathways in controlling growth and sensitivity to therapy-implications for cancer and aging. Aging (Albany NY). 2011; 3: 192-222.

42. Chappell WH, Steelman LS, Long JM, Kempf RC, Abrams SL, Franklin RA, Bäsecke J, Stivala F, Donia M, Fagone P, Malaponte G, Mazzarino MC, Nicoletti F, Libra M, Maksimovic-Ivanic D, Mijatovic S, et al. Ras/Raf/MEK/ ERK and PI3K/PTEN/Akt/mTOR inhibitors: rationale and importance to inhibiting these pathways in human health. Oncotarget. 2011; 2: 135-164.

43. Schmidt CM, McKillop IH, Cahill PA, Sitzmann JV. Increased MAPK expression and activity in primary human hepatocellular carcinoma. Biochem Biophys Res Commun. 1997; 236: 54-58.

44. Huynh H, Soo KC, Chow PK, Tran E. Targeted inhibition of the extracellular signal-regulated kinase kinase pathway with AZD6244 (ARRY-142886) in the treatment of hepatocellular carcinoma. Mol Cancer Ther. 2007; 6:138146.

45. Huynh H, Nguyen TT, Chow KH, Tan PH, Soo KC, Tran E. Over-expression of the mitogen-activated protein kinase (MAPK) kinase (MEK)-MAPK in hepatocellular carcinoma: its role in tumor progression and apoptosis. BMC Gastroenterol. 2003; 8: 3-19.

46. Ito Y, Sasaki Y, Horimoto M, Wada S, Tanaka Y, Kasahara A, Ueki T, Hirano T, Yamamoto H, Fujimoto J, Okamoto E, Hayashi N, Hori M. Activation of mitogen-activated protein kinases/extracellular signal-regulated kinases in human hepatocellular carcinoma. Hepatology. 1998; 27: 951-958.

47. Tanimura S, Chatani Y, Hoshino R, Sato M, Watanabe S, Kataoka T, Nakamura T, Kohno M. Activation of the 41/43 $\mathrm{kDa}$ mitogen-activated protein kinase signaling pathway is required for hepatocyte growth factor-induced cell scattering Oncogene. 1998; 17: 57-65.

48. Tsuboi $\mathrm{Y}$, Ichida $\mathrm{T}$, Sugitani $\mathrm{S}$, Genda $\mathrm{T}$, Inayoshi J, Takamura M, Matsuda Y, Nomoto M, Aoyagi Y. Overexpression of extracellular signal-regulated protein kinase and its correlation with proliferation in human 
hepatocellular carcinoma. Liver Int. 2004; 24: 432-436.

49. Calvisi DF, Ladu S, Gorden A, Farina M, Conner EA, Lee JS, Factor VM, Thorgeirsson SS. Ubiquitous activation of Ras and Jak/Stat pathways in human HCC. Gastroenterology. 2006; 130: 1117-1128.

50. Fong CW, Chua MS, McKie AB, Ling SH, Mason V, Li R, Yusoff P, Lo TL, Leung HY, So SK, Guy GR. Sprouty 2, an inhibitor of mitogen-activated protein kinase signaling, is down-regulated in hepatocellular carcinoma. Cancer Res. 2006; 66: 2048-2058.

51. Yoshida T, Hisamoto T, Akiba J, Koga H, Nakamura K, Tokunaga Y, Hanada S, Kumemura H, Maeyama M, Harada M, Ogata H, Yano H, Kojiro M, Ueno T, Yoshimura A, Sata M. Spreds, inhibitors of the Ras/ERK signal transduction, are dysregulated in human hepatocellular carcinoma and linked to the malignant phenotype of tumors. Oncogene. 2006; 25: 6056-6066.

52. Lee HC, Tian B, Sedivy JM, Wands JR, Kim M. Loss of Raf kinase inhibitor protein promotes cell proliferation and migration of human hepatoma cells. Gastroenterology. 2006; 131: 1208-1217.

53. Schuierer MM, Bataille F, Weiss TS, Hellerbrand C, Bosserhoff AK. Raf kinase inhibitor protein is downregulated in hepatocellular carcinoma. Oncol Rep. 2006; 16: 451-456.

54. Schmitz KJ, Wohlschlaeger J, Lang H, Sotiropoulos GC, Malago M, Steveling K, Reis H, Cicinnati VR, Schmid KW, Baba HA. Activation of the ERK and AKT signalling pathway predicts poor prognosis in hepatocellular carcinoma and ERK activation in cancer tissue is associated with hepatitis C virus infection. J Hepatol. 2008; 48: 83-90.

55. Saxena NK, Sharma D, Ding X, Lin S, Marra F, Merlin D, Anania FA. Concomitant activation of the JAK/ STAT, PI3K/AKT, and ERK signaling is involved in leptin-mediated promotion of invasion and migration of hepatocellular carcinoma cells. Cancer Res. 2007; 67: 2497 2507.

56. Natoli G, Avantaggiati ML, Chirillo P, Puri PL, Ianni A, Balsano C, Levrero M. Ras- and Raf-dependent activation of c-jun transcriptional activity by the hepatitis B virus transactivator pX. Oncogene. 1994; 9: 2837-2843.

57. Giambartolomei S, Covone F, Levrero M, Balsano C. Sustained activation of the Raf/MEK/Erk pathway in response to EGF in stable cell lines expressing the hepatitis $\mathrm{C}$ virus (HCV) core protein. Oncogene. 2001; 20: 26062010.

58. Benn J, Schneider RJ. Hepatitis B virus HBx protein activates Ras-GTP complex formation and establishes a Ras, Raf, MAP kinase signaling cascade. Proc Natl Acad Sci USA. 1994; 91: 10350-10354.

59. Yun C, Cho H, Kim SJ, Kim SJ, Lee JH, Park SY, Chan GK, Cho H. Mitotic aberration coupled with centrosome amplification is induced by hepatitis B virus $\mathrm{X}$ oncoprotein via the Ras-mitogen-activated protein/extracellular signal- regulated kinase-mitogen-activated protein pathway. Mol Cancer Res. 2004; 2: 159-169.

60. Chung TW, Lee YC, Kim CH. Hepatitis B viral HBx induces matrix metalloproteinase-9 gene expression through activation of ERK and PI-3K/AKT pathways: involvement of invasive potential. FASEB J. 2004; 18: 1123-1125.

61. Hayashi J, Aoki H, Kajino K, Moriyama M, Arakawa Y, Hino O. Hepatitis $\mathrm{C}$ virus core protein activates the MAPK/ ERK cascade synergistically with tumor promoter TPA, but not with epidermal growth factor or transforming growth factor alpha. Hepatology. 2000; 32: 958-961.

62. Aoki H, Hayashi J, Moriyama M, Arakawa Y, Hino O. Hepatitis $\mathrm{C}$ virus core protein interacts with 14-3-3 protein and activates the kinase Raf-1. J Virol. 2000; 74: 17361741.

63. Huynh H, Chow PK, Ooi LL, Soo KC. A possible role for insulin-like growth factor-binding protein-3 autocrine/ paracrine loops in controlling hepatocellular carcinoma cell proliferation. Cell Growth Differ. 2002; 13: 115-122.

64. Kannangai R, Sahin F, Torbenson MS. EGFR is phosphorylated at Ty845 in hepatocellular carcinoma. Mod Pathol. 2006; 19: 1456-1461.

65. Cardone MH, Roy N, Stennicke HR, , Salvesen GS, Franke TF, Stanbridge E, Frisch S, Reed JC. Regulation of cell death protease caspase- 9 by phosphorylation. Science. 1998; 282: 1318-1321.

66. del Peso L, Gonzalez-Garcia M, Page C, Herrera R, Nuñez G. Interleukin-3-induced phosphorylation of BAD through the protein kinase Akt. Science. 1997; 278: 687-689.

67. Datta SR, Dudek H, Tao X, Masters S, Fu H, Gotoh Y, Greenberg ME. Akt phosphorylation of BAD couples survival signals to the cell-intrinsic death machinery. Cell. 1997; 91: 231-241.

68. Cross DA, Alessi DR, Cohen P, Andjelkovich M, Hemmings BA. Inhibition of glycogen synthase kinase-3 by insulin mediated by protein kinase B. Nature. 1995; 378 : 785-789.

69. Kane LP, Shapiro VS, Stokoe D, Weiss A. Induction of NFkappaB by the Akt/PKB kinase. Curr Biol. 1999; 9: 601604.

70. Andjelkovic M, Alessi DR, Meier R, Fernandez A, Lamb NJ, Frech M, Cron P, Cohen P, Lucocq JM, Hemmings BA. Role of translocation in the activation and function of protein kinase B. J Biol Chem. 1997; 272: 31515-31524.

71. Du K, Montminy M. CREB is a regulatory target for the protein kinase Akt/PKB. J Biol Chem. 1998; 273: 3237732379.

72. Brennan P, Babbage JW, Burgering BM, Groner B, Reif K, Cantrell DA. Phosphatidylinositol 3-kinase couples the interleukin-2 receptor to the cell cycle regulator E2F. Immunity. 1997; 7: 679-689.

73. McClellan KA, Slack RS. Specific in vivo roles for E2Fs in differentiation and development. Cell Cycle. 2007; 6: 29172927. 
74. Brunet A, Bonni A, Zigmond MJ, Lin MZ, Juo P, Hu LS, Anderson MJ, Arden KC, Blenis J, Greenberg ME. Akt promotes cell survival by phosphorylating and inhibiting a Forkhead transcription factor. Cell. 1999; 96: 857-868.

75. Kops GJ, de Ruiter ND, De Vries-Smits AM, Powell DR, Bos JL, Burgering BM. Direct control of the Forkhead transcription factor AFX by protein kinase B. Nature. 1999; 398: 630-634.

76. Kops GJ, Burgering BM. Forkhead transcription factors are targets of signalling by the proto-oncogene PKB (C-AKT). J Anat. 2000; 197: 571-574.

77. Nakamura N, Ramaswamy S, Vazquez F, Vazquez F, Signoretti S, Loda M, Sellers WR. Forkhead transcription factors are critical effectors of cell death and cell cycle arrest downstream of PTEN. Mol Cell Biol. 2000; 20: 89698982.

78. Calvisi DF, Ladu S, Gorden A, Farina M, Lee JS, Conner EA, Schroeder I, Factor VM, Thorgeirsson SS. Mechanistic and prognostic significance of aberrant methylation in the molecular pathogenesis of human hepatocellular carcinoma. J Clin Invest. 2007; 117: 2713-2722.

79. Nakanishi K, Sakamoto M, Yamasaki S, Todo S, Hirohashi $\mathrm{S}$. Akt phosphorylation is a risk factor for early disease recurrence and poor prognosis in hepatocellular carcinoma. Cancer. 2005; 103: 307-312.

80. $\mathrm{Hu} \mathrm{TH}$, Huang CC, Lin PR, Chang HW, Ger LP, Lin YW, Changchien CS, Lee CM, Tai MH. Expression and prognostic role of tumor suppressor gene PTEN/MMAC1/ TEP1 in hepatocellular carcinoma. Cancer. 2003; 97: 19291940.

81. Suzuki A, Nakano T, Mak TW, Sasaki T. Portrait of PTEN: messages from mutant mice. Cancer Sci. 2008; 99: 209-213.

82. Yao YJ, Ping XL, Zhang H, Chen FF, Lee PK, Ahsan H, Chen CJ, Lee PH, Peacocke M, Santella RM, Tsou HC. PTEN/MMAC1 mutations in hepatocellular carcinomas. Oncogene. 1999; 18: 3181-3185.

83. Yeh KT, Chang JG, Chen YJ, Chen ST, Yu SY, Shih MC, Perng LI, Wang JC, Tsai M, Chang CP. Mutation analysis of the putative tumor suppressor gene PTEN/MMAC1 in hepatocellular carcinoma. Cancer Invest. 2000; 18: 123129.

84. Kawamura N, Nagai H, Bando K, Koyama M, Matsumoto S, Tajiri T, Onda M, Fujimoto J, Ueki T, Konishi N, Shiba T, Emi M. PTEN/MMAC1 mutations in hepatocellular carcinomas: somatic inactivation of both alleles in tumors. Jpn J Cancer Res. 1999; 90: 413-418.

85. Fujiwara Y, Hoon DS, Yamada T, Umeshita K, Gotoh M, Sakon M, Nishisho I, Monden M. PTEN/MMAC1 mutation and frequent loss of heterozygosity identified in chromosome 10q in a subset of hepatocellular carcinomas. Jpn J Cancer Res. 2000; 91: 287-292.

86. Wang L, Wang WL, Zhang Y, Guo SP, Zhang J, Li QL. Epigenetic and genetic alterations of PTEN in hepatocellular carcinoma. Hepatol Res. 2007; 37: 389-396.
87. Rahman MA, Kyriazanos ID, Ono T, Yamanoi A, Kohno $\mathrm{H}$, Tsuchiya M, Nagasue N. Impact of PTEN expression on the outcome of hepatitis $\mathrm{C}$ virus-positive cirrhotic hepatocellular carcinoma patients: possible relationship with COX II and inducible nitric oxide synthase. Int $\mathbf{J}$ Cancer. 2002; 100: 152-157.

88. Hu TH, Wang CC, Huang CC, Chen CL, Hung CH, Chen $\mathrm{CH}$, Wang JH, Lu SN, Lee CM, Changchien CS, Tai MH. Down-regulation of tumor suppressor gene PTEN, overexpression of $\mathrm{p} 53$, plus high proliferating cell nuclear antigen index predict poor patient outcome of hepatocellular carcinoma after resection. Oncol Rep. 2007; 18: 1417-1426.

89. Lee YI, Kang-Park S, Do SI, Lee YI. The hepatitis B virus-X protein activates a phosphatidylinositol 3-kinasedependent survival signaling cascade. J Biol Chem. 2001; 276: 16969-16977.

90. Mannová P, Beretta L. Activation of the N-Ras-PI3K-AktmTOR pathway by hepatitis $C$ virus: control of cell survival and viral replication. J Virol. 2005; 79: 8742-8749.

91. Chung TW, Lee YC, Ko JH, Kim CH. Hepatitis B Virus $\mathrm{X}$ protein modulates the expression of PTEN by inhibiting the function of $\mathrm{p} 53$, a transcriptional activator in liver cells. Cancer Res. 2003; 63: 3453-3458.

92. Kang-Park S, Im JH, Lee JH, Lee YI. PTEN modulates hepatitis B virus-X protein induced survival signaling in Chang liver cells. Virus Res. 2006; 122: 53-60.

93. Schumacher G, Oidtmann M, Rosewicz S, Langrehr J, Jonas S, Mueller AR,. Rueggeberg A, Neuhaus R, Bahra M, Jacob D, Gerlach H, Neuhaus P. Sirolimus inhibits growth of human hepatoma cells in contrast to tacrolimus, which promotes cell growth. Transplant Proc. 2002; 34: 13921393.

94. Villanueva A, Chiang DY, Newell P, Peix J, Thung $\mathrm{S}$, Alsinet C, Tovar V, Roayaie S, Minguez B, Sole M, Battiston C, Van Laarhoven S, Fiel MI, Di Feo A, Hoshida Y, Yea S, et al. Pivotal role of mTOR signaling in hepatocellular carcinoma. Gastroenterology 2008; 135: 1972-1983.

95. Scharf JG, Braulke T. The role of the IGF axis in hepatocarcinogenesis. Horm Metab Res. 2003; 35: 685-693.

96. Nussbaum T, Samarin J, Ehemann V, Bissinger M, Ryschich E, Khamidjanov A, Yu X, Gretz N, Schirmacher $\mathrm{P}$, Breuhahn K. Autocrine insulin-like growth factor-II stimulation of tumor cell migration is a progression step in human hepatocarcinogenesis. Hepatology. 2008; 48: 146156.

97. Breuhahn K, Schirmacher P. Reactivation of the insulin-like growth factor-II signaling pathway in human hepatocellular carcinoma. World J Gastroenterol. 2008; 14: 1690-1698.

98. Cariani E, Lasserre C, Seurin D, Hamelin B, Kemeny F, Franco D, Czech MP, Ullrich A, Brechot C. Differential expression of insulin-like growth factor II mRNA in human primary liver cancers, benign liver tumors, and liver cirrhosis. Cancer Res. 1988; 48: 6844-6849. 
99. Cariani E, Seurin D, Lasserre C, Franco D, Binoux M, Brechot C. Expression of insulin-like growth factor II (IGF-II) in human primary liver cancer: mRNA and protein analysis. J Hepatol. 1990; 11: 226-231.

100. Breuhahn K, Vreden S, Haddad R, Beckebaum S, Stippel D, Flemming P, Nussbaum T, Caselmann WH, Haab BB, Schirmacher P. Molecular profiling of human hepatocellular carcinoma defines mutually exclusive interferon regulation and insulin-like growth factor II overexpression. Cancer Res. 2004; 64: 6058-6064.

101. Vu TH, Hoffman AR. Promoter-specific imprinting of the human insulin-like growth factor-II gene. Nature. 1994; 371: 714-717.

102. Lee S, Park U, Lee YI. Hepatitis C virus core protein transactivates insulin-like growth factor II gene transcription through acting concurrently on Egr1 and Sp1 sites. Virology. 2001; 283: 167-177.

103. Lee YI, Lee S, Lee Y, Bong YS, Hyun SW, Yoo YD, Kim SJ, Kim YW, Poo HR. The human hepatitis B virus transactivator $\mathrm{X}$ gene product regulates $\mathrm{Sp} 1$ mediated transcription of an insulin-like growth factor II promoter 4. Oncogene. 1998; 16: 2367-2380.

104. Bruix J, Llovet JM. Major achievements in hepatocellular carcinoma. Lancet. 2009; 373: 614-616.

105. Calle EE, Rodriguez C, Walker-Thurmond K, Thun MJ. Overweight, obesity, and mortality from cancer in a prospectively studied cohort of US adults. N Engl J Med. 2003; 348: 1625-1638.

106. de La Coste A, Romagnolo B, Billuart P, Renard CA, Buendia MA, Soubrane O, Fabre M, Chelly J, Beldjord C, Kahn A, Perret C. Somatic mutations of the beta-catenin gene are frequent in mouse and human hepatocellular carcinomas. Proc Natl Acad Sci USA. 1998; 95: 8847-8851.

107. Zucman-Rossi J, Benhamouche S, Godard C, Boyault S, Grimber G, Balabaud C, Cunha AS, Bioulac-Sage P, Perret C. Differential effects of inactivated Axin1 and activated beta-catenin mutations in human hepatocellular carcinomas. Oncogene. 2007; 26: 774-780.

108. Fujie H, Moriya K, Shintani Y, Tsutsumi T, Takayama T, Makuuchi M, Kimura S, Koike K. Frequent beta-catenin aberration in human hepatocellular carcinoma. Hepatol Res. 2001; 20: 39-51.

109. Huang H, Fujii H, Sankila A, Mahler-Araujo BM, Matsuda M, Cathomas G, Beta-catenin mutations are frequent in human hepatocellular carcinomas associated with hepatitis C virus infection. Am J Pathol. 1999; 155: 1795-1801.

110. Kim YD, Park CH, Kim HS, Choi SK, Rew JS, Kim DY, Koh YS, Jeung KW, Lee KH, Lee JS, Juhng SW, Lee JH. Genetic alterations of Wnt signaling pathway-associated genes in hepatocellular carcinoma. J Gastroenterol Hepatol. 2008; 23: 110-118.

111. Kondo Y, Kanai Y, Sakamoto M, Genda T, Mizokami M, Ueda R, Hirohashi S. Beta-catenin accumulation and mutation of exon 3 of the beta-catenin gene in hepatocellular carcinoma. Jpn J Cancer Res. 1999; 90: 1301-1309.

112. Carruba G, Cervello M, Miceli MD, Farruggio R, Notarbartolo M, Virruso L, Giannitrapani L, Gambino R, Montalto G, Castagnetta L. Truncated form of beta-catenin and reduced expression of wild-type catenins feature HepG2 human liver cancer cells. Ann N Y Acad Sci. 1999; 886: 212-216.

113. Wong CM, Fan ST, Ng IO. $\beta$-Catenin mutation and overexpression in hepatocellular carcinoma: clinicopathologic and prognostic significance. Cancer. 2001; 92: 136-145.

114. Cha MY, Kim CM, Park YM, Ryu WS. Hepatitis B virus $\mathrm{X}$ protein is essential for the activation of Wnt/beta-catenin signaling in hepatoma cells. Hepatology. 2004; 39: 16831693.

115. Lian Z, Liu J, Li L, Li X, Clayton M, Wu MC, Wang HY, Arbuthnot P, Kew M, Fan D, Feitelson MA. Enhanced cell survival of Hep3B cells by the hepatitis B $\mathrm{x}$ antigen effector, URG11, is associated with upregulation of betacatenin. Hepatology. 2006; 43: 415-424.

116. Satoh S, Daigo Y, Furukawa Y, Kato T, Miwa N, Nishiwaki $\mathrm{T}$, Kawasoe T, Ishiguro H, Fujita M, Tokino T, AXIN1 mutations in hepatocellular carcinomas, and growth suppression in cancer cells by virus-mediated transfer of AXIN1. Nat Genet. 2000; 24: 245-250.

117. Huang SM, Mishina YM, Liu S, Cheung A, Stegmeier F, Michaud GA, Charlat O, Wiellette E, Zhang Y, Wiessner S, Hild M, Shi X, Wilson CJ, Mickanin C, Myer V, Fazal A, et al. Tankyrase inhibition stabilizes axin and antagonizes Wnt signalling. Nature. 2009; 461: 614-620.

118. Merle P, de la Monte S, Kim M, Herrmann M, Tanaka S, Von Dem Bussche A, Kew MC, Trepo C, Wands JR. Functional consequences of frizzled-7 receptor overexpression in human hepatocellular carcinoma. Gastroenterology. 2004; 127: 1110-1122.

119. Merle P, Kim M, Herrmann M, Gupte A, Lefrancois L, Califano S, Trépo C, Tanaka S, Vitvitski L, de la Monte $\mathrm{S}$, Wands JR. Oncogenic role of the frizzled-7/beta-catenin pathway in hepatocellular carcinoma. J Hepatol. 2005; 43: 854-862.

120. Kim M, Lee HC, Tsedensodnom O, Hartley R, Lim YS, $\mathrm{Yu}$ E, Merle P, Wands JR. Functional interaction between Wnt3 and Frizzled-7 leads to activation of the Wnt/betacatenin signaling pathway in hepatocellular carcinoma cells. J Hepatol. 2008; 48: 780-791.

121. Nambotin SB, Lefrancois L, Sainsily X, Berthillon P, Kim M, Wands JR, Chevallier M, Jalinot P, Scoazec JY, Trepo C, Zoulim F, Merle P. Pharmacological inhibition of Frizzled-7 displays anti-tumor properties in hepatocellular carcinoma. J Hepatol. 2011; 54: 288-299.

122. Zeng G, Apte U, Cieply B, Singh S, Monga SP. siRNAmediated beta-catenin knockdown in human hepatoma cells results in decreased growth and survival. Neoplasia. 2007; 9: 951-959. 
123. Ingham PW, McMahon AP. Hedgehog signaling in animal development: paradigms and principles. Genes Dev. 2001; 15: 3059-3087.

124. Ruiz i Altaba A, Sanchez P, Dahmane N. Gli and hedgehog in cancer: tumours, embryos and stem cells. Nat Rev Cancer. 2002; 2, 361-372.

125. Lin SL, Chang SJ, Ying SY. Transcriptional control of SHh/ PTC1 signaling in embryonic development. Gene. 2006; 367: 56-65.

126. Deutsch G, Jung J, Zheng M, Lora J, Zaret KS. A bipotential precursor population for pancreas and liver within the embryonic endoderm. Development. 2001; 128: 871-881.

127. Omenetti A, Diehl AM. The adventures of sonic hedgehog in development and repair. II. Sonic hedgehog and liver development, inflammation, and cancer. Am J Physiol Gastrointest Liver Physiol. 2008; 294: G595-G598.

128. Omenetti A, Choi S, Michelotti G, Diehl AM. Hedgehog signaling in the liver. J Hepatol. 2011; 54: 366-373.

129. Hui CC, Angers S. Gli Proteins in Development and Disease. Annu Rev Cell Dev Biol. 2011; 27: 513-537.

130. Pasca di Magliano M, Hebrok M. Hedgehog signalling in cancer formation and maintenance. Nat Rev Cancer. 2003; 3: $903-911$.

131. Huang S, He J, Zhang X, Bian Y, Yang L, Xie G, Zhang K, Tang W, Stelter AA, Wang Q, Zhang H, Xie J. Activation of the hedgehog pathway in human hepatocellular carcinomas. Carcinogenesis. 2006; 27: 1334-1340.

132. Patil MA, Zhang J, Ho C, Cheung ST, Fan ST, Chen X.. Hedgehog signaling in human hepatocellular carcinoma. Cancer Biol Ther. 2006; 5: 111-117.

133. Sicklick JK. Dysregulation of the hedgehog pathway in human hepatocarcinogenesis. Carcinogenesis. 2006; 27: 748-757.

134. Kim Y, Yoon JW, Xiao X, Dean NM, Monia BP, Marcusson EG. Selective down-regulation of glioma-associated oncogene 2 inhibits the proliferation of hepatocellular carcinoma cells. Cancer Res. 2007; 67: 3583-3593.

135. Cheng WT, Xu K, Tian DY, Zhang ZG, Liu LJ, Chen Y. Role of Hedgehog signaling pathway in proliferation and invasiveness of hepatocellular carcinoma cells. Int J Oncol. 2009; 34: 829-836.

136. Pereira Tde A, Witek RP, Syn WK, Choi SS, Bradrick S, Karaca GF, Agboola KM, Jung Y, Omenetti A, Moylan CA, Yang L, Fernandez-Zapico ME, Jhaveri R, Shah VH, Pereira FE, Diehl AM. Viral factors induce Hedgehog pathway activation in humans with viral hepatitis, cirrhosis, and hepatocellular carcinoma. Lab Invest. 2010; 90: 16901703.

137. Mullor JL, Dahmane N, Sun T, Ruizi Altaba A. Wnt signals are targets and mediators of Gli function. Curr Biol. 2001; 11: 769-773.

138. Niemann C, Unden AB, Lyle S, Zouboulis ChC, Toftgard $\mathrm{R}$, Watt FM. Indian hedgehog and $\beta$-catenin signaling: role in the sebaceous lineage of normal and neoplastic mammalian epidermis. Proc Natl Acad Sci USA. 2003; 1: 11873-11880.

139. Balkwill F, Charles KA, Mantovani A. Smoldering and polarized inflammation in the initiation and promotion of malignant disease. Cancer Cell. 2005; 7: 211-217.

140. Balkwill F, Mantovani A. Cancer and inflammation: implications for pharmacology and therapeutics. Clin Pharmacol Ther. 2010; 87: 401-406.

141. He G, Karin M. NF- $\kappa$ B and STAT3 key players in liver inflammation and cancer. Cell Res. 2011; 21: 159-168.

142. Berasain C, Castillo J, Perugorria MJ, Latasa MU, Prieto J, Avila MA. Inflammation and liver cancer: new molecular links . Ann N Y Acad Sci. 2009; 1155: 206-221.

143. Vakkila J, Lotze MT. Inflammation and necrosis promote tumour growth. Nat Rev Immunol. 2004; 4: 641-648.

144. Rose-John S, Heinrich PC. Soluble receptors for cytokines and growth factors: generation and biological function. Biochem J. 1994; 300: 281-290.

145. Naugler WE, Karin M. The wolf in sheep's clothing: the role of interleukin-6 in immunity, inflammation and cancer. Trends Mol Med. 2008; 14: 109-119.

146. Naugler WE, Sakurai T, Kim S, Maeda S, Kim K, Elsharkawy AM, Karin M. Gender disparity in liver cancer due to sex differences in MyD88-dependent IL-6 production. Science. 2007; 317: 121-124.

147. Giannitrapani L, Soresi M, La Spada E, Cervello M, D'Alessandro N, Montalto G. Sex hormones and risk of liver tumor. Ann N Y Acad Sci. 2006; 1089: 228-236.

148. Nakagawa H, Maeda S, Yoshida H, Tateishi R, Masuzaki R, Ohki T, Hayakawa Y, Kinoshita H, Yamakado M, Kato N, Shiina S, Omata M. Serum IL-6 levels and the risk for hepatocarcinogenesis in chronic hepatitis $\mathrm{C}$ patients: an analysis based on gender differences. Int J Cancer. 2009; 125: 2264-2269.

149. Li Z, Tuteja G, Schug J, Kaestner KH. Foxa1 and Foxa2 are essential for sexual dimorphism in liver cancer. Cell. 2012; 148: 72-83.

150. Goydos JS, Brumfield AM, Frezza E, Booth A, Lotze MT, Carty SE. Marked elevation of serum interleukin 6 in patients with cholangiocarcinoma. Ann Surg. 1998; 227: 398-404.

151. Giannitrapani L, Cervello M, Soresi M, Notarbartolo M, La Rosa M, Virruso L, D’Alessandro N, Montalto G. Circulating IL 6 and sIL 6R in patients with hepatocellular carcinoma. Ann NY Acad Sci. 2002; 963: 46-52.

152. Giannitrapani L, Soresi M, Giacalone A, Campagna ME, Marasà M, Cervello M, Marasà S, Montalto G. IL-6 -174G/ C polymorphism and IL-6 serum levels in patients with liver cirrhosis and hepatocellular carcinoma. OMICS. 2011; 15: 183-186.

153. Malaguarnera M, Di Fazio I, Taurini A,. Romeo MA, Giugno I, Trovato BA. Role of interleukin 6 in hepatocellular carcinoma. Bull Cancer. 1996; 83: 379-384. 
154. Soresi M, Giannitrapani L, D'Antona F, Florena AM, La Spada E, Terranova A, Cervello M, D'Alessandro $\mathrm{N}$, Montalto G. Interleukin-6 and its soluble receptor in patients with liver cirrhosis and hepatocellular carcinoma. World J Gastroenterol. 2006; 12: 2563-2568.

155. Bromberg JF, Wrzeszczynska MH, Devgan G, Zhao Y, Pestell RG, Albanese C, Darnell JE Jr. Stat3 as an oncogene. Cell. 1999; 98: 295-303.

156. Yang SF, Wang SN, Wu CF, Yeh YT, Chai CY, Chunag SC, Sheen MC, Lee KT. Altered p-STAT3 (tyr705) expression is associated with histological grading and intratumour microvessel density in hepatocellular carcinoma. J Clin Pathol. 2007; 60: 642-648.

157. Lin L, Amin R, Gallicano GI, Glasgow E, Jogunoori W, Jessup JM, Zasloff M, Marshall JL, Shetty K, Johnson L, Mishra L, He AR. The STAT3 inhibitor NSC 74859 is effective in hepatocellular cancers with disrupted TGF-beta signaling. Oncogene. 2009; 28: 961-972.

158. Wang XH, Liu BR, Qu B, Xing H, Gao SL, Yin JM, Wang XF, Cheng YQ. Silencing STAT3 may inhibit cell growth through regulating signaling pathway, telomerase, cell cycle, apoptosis and angiogenesis in hepatocellular carcinoma: potential uses for gene therapy. Neoplasma. 2011; 58: 158-171.

159. Lavecchia A, Di Giovanni C, Novellino E. STAT-3 inhibitors: state of the art and new horizons for cancer treatment. Curr Med Chem. 2011; 18: 2359-2375.

160. Liu Y, Fuchs J, Li C, Lin J. IL-6, a risk factor for hepatocellular carcinoma: FLLL32 inhibits IL-6-induced STAT3 phosphorylation in human hepatocellular cancer cells. Cell Cycle. 2010; 9: 3423-3427.

161. Cuzick J, Otto F, Baron JA, Brown PH, Burn J, Greenwald P, Jankowski J, La Vecchia C, Meyskens F, Senn HJ, Thun M. Aspirin and non-steroidal anti-inflammatory drugs for cancer prevention: an international consensus statement. Lancet Oncol. 2009; 10: 501-507.

162. Zha S, Yegnasubramanian V, Nelson WG, Isaacs WB, De Marzo AM. Cyclooxygenases in cancer: progress and perspective. Cancer Lett. 2004; 215: 1-20.

163. Koga H, Sakisaka S, Ohishi M, Kawaguchi T, Taniguchi E, Sasatomi K, Harada M, Kusaba T, Tanaka M, Kimura R, Nakashima Y, Nakashima O, Kojiro M, Kurohiji T, Sata M. Expression of cyclooxygenase-2 in human hepatocellular carcinoma: relevance to tumor dedifferentiation. Hepatology. 1999; 29: 688-696.

164. Cervello M, Foderà D, Florena AM, Soresi M, Tripodo C, D'Alessandro N, Montalto G. Correlation between expression of cyclooxygenase- 2 and the presence of inflammatory cells in human primary hepatocellular carcinoma: possible role in tumor promotion and angiogenesis. World J Gastroenterol. 2005; 11: 4638-4643.

165. Schmitz KJ, Wohlschlaeger J, Lang H, Sotiropoulos GC, Kaiser GM, Schmid KW, Baba HA. Cyclo-oxygenase-2 overexpression is a feature of early and well-differentiated hepatocellular carcinoma with a favourable prognosis. J Clin Pathol. 2009; 62: 690-693.

166. He YF, Jin J, Wei W, Chang Y, Hu B, Ji CS, Jia WD, Wang $\mathrm{XQ}$, Chen K, Chen J. Overexpression of cyclooxygenase-2 in noncancerous liver tissue increases the postoperative recurrence of hepatocellular carcinoma in patients with hepatitis B virus-related cirrhosis. Can J Gastroenterol. 2010; 24: 435-440.

167. Kondo M, Yamamoto H, Nagano H, Okami J, Ito Y, Shimizu J, Eguchi H, Miyamoto A, Dono K, Umeshita K, Matsuura N, Wakasa K, Nakamori S, Sakon M, Monden $\mathrm{M}$. Increased expression of COX-2 in nontumor liver tissue is associated with shorter disease-free survival in patients with hepatocellular carcinoma. Clin Cancer Res. 1999; 5: 4005-4012.

168. Cervello M, Montalto G. Cyclooxygenases in hepatocellular carcinoma. World J Gastroenterol. 2006; 12: 5113-5121.

169. Márquez-Rosado L, Trejo-Solís MC, García-Cuéllar CM, Villa-Treviño S. Celecoxib, a cyclooxygenase-2 inhibitor, prevents induction of liver preneoplastic lesions in rats. $\mathrm{J}$ Hepatol. 2005; 43: 653-660.

170. Kern MA, Schoneweiss MM, Sahi D, Bahlo M, Haugg AM, Kasper HU, Dienes HP, Kaferstein H, Breuhahn K, Schirmacher P. Cyclooxygenase-2 inhibitors suppress the growth of human hepatocellular carcinoma implants in nude mice. Carcinogenesis. 2004; 25: 1193-1199.

171. Bae SH, Jung ES, Park YM, Kim BS, Kim BK, Kim DG, Ryu WS. Expression of cyclooxigenase-2 (COX2) in hepatocellular carcinoma and growth inhibition of hepatoma cell lines by a COX-2 inhibitor, NS-398. Clin Cancer Res. 2001; 7: 1410-1418.

172. Foderà D, D'Alessandro $\mathrm{N}$, Cusimano $\mathrm{A}$, Poma $\mathrm{P}$, Notarbartolo M, Lampiasi N, Montalto G, Cervello M. Induction of apoptosis and inhibition of cell growth in human hepatocellular carcinoma cells by COX-2 inhibitors. Ann N Y Acad Sci. 2004; 1028: 440-449.

173. Schmidt CM, Wang Y, Wiesenauer C. Novel combination of cyclooxygenase-2 and MEK inhibitors in human hepatocellular carcinoma provides a synergistic increase in apoptosis. J Gastrointest Surg. 2003; 7: 1024-1033.

174. Cusimano A, Foderà D, D'Alessandro N, Lampiasi N, Azzolina A, Montalto G, Cervello M. Potentiation of the antitumor effects of both selective cyclooxygenase-1 and cyclooxygenase- 2 inhibitors in human hepatic cancer cells by inhibition of the MEK/ERK pathway. Cancer Biol Ther. 2007; 6: 1461-1468.

175. Leng J, Han C, Demetris AJ, Michalopoulos GK, Wu T. Cyclooxygenase-2 promotes hepatocellular carcinoma cell growth through Akt activation: evidence for Akt inhibition in celecoxib-induced apoptosis. Hepatology. 2003; 38: 756768 .

176. Kulp SK, Yang YT, Hung CC, Chen KF, Lai JP, Tseng PH, Fowble JW, Ward PJ, Chen CS. 3-phosphoinositidedependent protein kinase-1/Akt signaling represents a 
major cyclooxygenase-2-independent target for celecoxib in prostate cancer cells. Cancer Res. 2004; 64: 1444-1451.

177. Pyrko P, Soriano N, Kardosh A, Liu YT, Uddin J, Petasis NA, Hofman FM, Chen CS, Chen TC, Schonthal AH. Downregulation of survivin expression and concomitant induction of apoptosis by celecoxib and its noncyclooxygenase-2-inhibitory analog, dimethyl-celecoxib (DMC), in tumor cells in vitro and in vivo. Mol Cancer. 2006; 18: 5-19.

178. Rudner J, Elsaesser SJ, Muller AC, Belka C, Jendrossek V. Differential effects of anti-apoptotic Bcl-2 family members Mcl-1, Bcl-2, and Bcl-xL on celecoxib-induced apoptosis. Biochem Pharmacol. 2010; 79: 10-20.

179. Lin HP, Kulp SK, Tseng PH, Yang YT, Yang CC, Chen CS. Growth inhibitory effects of celecoxib in human umbilical vein endothelial cells are mediated through G1 arrest via multiple signaling mechanisms. Mol Cancer Ther. 2004; 3: 1671-1680.

180. Johnson AJ, Hsu AL, Lin HP, Song X, Chen CS. The cyclooxygenase-2 inhibitor celecoxib perturbs intracellular calcium by inhibiting endoplasmic reticulum $\mathrm{Ca} 2+$ ATPases: a plausible link with its anti-tumour effect and cardiovascular risks. Biochem J. 2002; 366: 831-837.

181. Cervello M, Bachvarov D, Cusimano A, Sardina F, Azzolina A, Lampiasi N, Giannitrapani L, McCubrey JA, Montalto G. COX-2-dependent and COX-2-independent mode of action of celecoxib in human liver cancer cells OMICS. 2011; 15: 383-392.

182. Cusimano A, Azzolina A, Iovanna JL, Bachvarov D, McCubrey JA, D'Alessandro N, Montalto G, Cervello M. Novel combination of celecoxib and proteasome inhibitor MG132 provides synergistic antiproliferative and proapoptotic effects in human liver tumor cells. Cell Cycle. 2010; 9: 1399-1410.

183. Liu Y, Liu A, Li H, Li C, Lin J. Celecoxib inhibits Interleukin-6/Interleukin-6 receptor-induced JAK2/STAT3 phosphorylation in human hepatocellular carcinoma cells. Cancer Prev Res. 2011; 4: 1296-1305.

184. Karin M, Greten FR. NF-kappaB: linking inflammation and immunity to cancer development and progression. Nat Rev Immunol. 2005; 5: 749-759.

185. Arsura M, Cavin LG. Nuclear factor-kappaB and liver carcinogenesis. Cancer Lett. 2005; 229: 157-169.

186. Luedde T, Schwabe RF. NF-кB in the liver- linking injury, fibrosis and hepatocellular carcinoma. Nat Rev Gastroenterol Hepatol. 2011; 8: 108-118.

187. Tai DI, Tsai SL, Chen YM, Chuang YL, Peng CY, Sheen IS, Yeh CT, Chang KS, Huang SN, Kuo GC, Liaw YF. Activation of nuclear factor kappaB in hepatitis $\mathrm{C}$ virus infection: implications for pathogenesis and hepatocarcinogenesis. Hepatology. 2000; 31: 656-664.

188. Liu P, Kimmoun E, Legrand A, Sauvanet A, Degott C, Lardeux B, Bernuau D. Activation of NF-kappa B, AP-1 and STAT transcription factors is a frequent and early event in human hepatocellular carcinomas. J Hepatol. 2002; 37 : 63-71.

189. Poma P, Notarbartolo M, Labbozzetta M, Sanguedolce R, Alaimo A, Carina V, Maurici A, Cusimano A, Cervello M, D'Alessandro N. Antitumor effects of the novel NF-kappaB inhibitor dehydroxymethyl-epoxyquinomicin on human hepatic cancer cells: analysis of synergy with cisplatin and of possible correlation with inhibition of pro-survival genes and IL-6 production. Int J Oncol. 2006; 28: 923-930.

190. Wu JM, Sheng H, Saxena R, Skill NJ, Bhat-Nakshatri P, Yu M, Nakshatri H, Maluccio MA. NF-kappaB inhibition in human hepatocellular carcinoma and its potential as adjunct to sorafenib based therapy. Cancer Lett. 2009; 278: 145155.

191. Lampiasi N, Azzolina A, D’Alessandro N, Umezawa K, McCubrey JA, Montalto G, Cervello M. Antitumor effects of dehydroxymethylepoxyquinomicin, a novel nuclear factor-kappaB inhibitor, in human liver cancer cells are mediated through a reactive oxygen species-dependent mechanism. Mol Pharmacol. 2009; 76: 290-300.

192. Lavon I, Pikarsky E, Gutkovich E, Goldberg I, Bar J, Oren M, Ben-Neriah Y Nuclear factor-kappaB protects the liver against genotoxic stress and functions independently of p53. Cancer Res. 2003; 63: 25-30.

193. Subhashini J, Mahipal SV, Reddanna P. Anti-proliferative and apoptotic effects of celecoxib on human chronic myeloid leukemia in vitro. Cancer Lett. 2005; 224: 31-43.

194. Funakoshi-Tago M, Shimizu T, Tago K, Nakamura M, Itoh H, Sonoda Y, Kasahara T. Celecoxib potently inhibits TNFalpha-induced nuclear translocation and activation of NF-kappaB. Biochem Pharmacol. 2008; 76: 662-671.

195. Lampiasi N, Azzolina A, Umezawa K, Montalto G, McCubrey JA, Cervello M. The novel NF- $\mathrm{B}$ inhibitor DHMEQ synergizes with celecoxib to exert antitumor effects on human liver cancer cells by a ROS-dependent mechanism. Cancer Lett. 2012; in press

196. Park EJ, Lee JH, Yu GY, He G, Ali SR, Holzer RG, Osterreicher $\mathrm{CH}$, Takahashi $\mathrm{H}$, Karin M. Dietary and genetic obesity promote liver inflammation and tumorigenesis by enhancing IL-6 and TNF expression. Cell. 2010; 140: 197-208.

197. Giannelli G, Mazzocca A, Fransvea E, Lahn M, Antonaci S. Inhibiting TGF- $\beta$ signaling in hepatocellular carcinoma. Biochim Biophys Acta. 2011; 1815: 214-223.

198. Ueki T, Fujimoto J, Suzuki T, Yamamoto H, Okamoto E. Expression of hepatocyte growth factor and its receptor, the c-met proto-oncogene, in hepatocellular carcinoma. Hepatology. 1997; 25: 619-623.

199. Kaposi-Novak P, Lee JS, Gomez-Quiroz L, Coulouarn C, Factor VM, Thorgeirsson SS. Met-regulated expression signature defines a subset of human hepatocellular carcinomas with poor prognosis and aggressive phenotype. J Clin Invest. 2006; 116: 1582-1595.

200. Osada S, Kanematsu M, Imai H, Goshima S. Clinical 
significance of serum HGF and c-Met expression in tumor tissue for evaluation of properties and treatment of hepatocellular carcinoma. Hepatogastroenterology. 2008; 55: 544-549.

201. Avruch J, Zhou D, Fitamant J, Bardeesy N. Mst1/2 signalling to Yap: gatekeeper for liver size and tumour development. Br J Cancer. 2011; 104: 24-32.

202. Gramantieri L, Giovannini C, Lanzi A, Chieco P, Ravaioli M, Venturi A, Grazi GL, Bolondi L. Aberrant Notch3 and Notch4 expression in human hepatocellular carcinoma. Liver Int. 2007; 27: 997-1007.

203. Gao J, Song Z, Chen Y, Xia L, Wang J, Fan R, Du R, Zhang F, Hong L, Song J, Zou X, Xu H, Zheng G, Liu J, Fan D. Deregulated expression of Notch receptors in human hepatocellular carcinoma. Dig Liver Dis. 2008; 40: 114121.

204. Porta C, Paglino C. Medical treatment of unresectable hepatocellular carcinoma: Going beyond sorafenib. World J Hepatol. 2010; 2: 103-113.

205. Pircher A, Medinger M, Drevs J. Liver cancer: Targeted future options. World J Hepatol. 2011; 3: 38-44.

206. Villanueva A, Llovet JM. Targeted therapies for hepatocellular carcinoma. Gastroenterology. 2011; 140: 1410-1426.

207. Lord R, Suddle A, Ross PJ. Emerging strategies in the treatment of advanced hepatocellular carcinoma: the role of targeted therapies. Int J Clin Pract. 2011; 65: 182-188.

208. Faivre S, Bouattour M, Raymond E. Novel molecular therapies in hepatocellular carcinoma. Liver Int. 2011; 1: 151-160.

209. Iyer R, Fetterly G, Lugade A, Thanavala Y. Sorafenib: a clinical and pharmacologic review. Expert Opin Pharmacother. 2010; 11: 1943-1955.

210. Samant RS, Shevde LA. Recent advances in anti-angiogenic therapy of cancer. Oncotarget. 2011; 2: 122-134.

211. Llovet JM, Ricci S, Mazzaferro V, Hilgard P, Gane E, Blanc JF, de Oliveira AC, Santoro A, Raoul JL, Forner A, Schwartz M, Porta C, Zeuzem S, Bolondi L, Greten TF, Galle PR, et al.; SHARP Investigators Study Group. Sorafenib in advanced hepatocellular carcinoma. N Engl J Med. 2008; 359: 378-390.

212. Abou-Alfa GK, Johnson P, Knox J, et al. Final results from a phase II (PhII), randomized, double-blind study of sorafenib plus doxorubicin $(\mathrm{S}+\mathrm{D})$ versus placebo plus doxorubicin $(\mathrm{P}+\mathrm{D})$ in patients (pts) with advanced hepatocellular carcinoma (AHCC). ASCO 2008 Gastrointestinal Cancers Symposium (Abstract 128).

213. Huynh H, Nguyen TT, Chow KH, Tan PH, Soo KC, Tran E. Over-expression of the mitogen-activated protein kinase (MAPK) kinase (MEK)-MAPK in hepatocellular carcinoma: its role in tumor progression and apoptosis. BMC Gastroenterol. 2003; 3: 19.

214. Tsuboi Y, Ichida T, Sugitani S, Genda T, Inayoshi J, Takamura M, Matsuda Y, Nomoto M, Aoyagi Y.
Overexpression of extracellular signal-regulated protein kinase and its correlation with proliferation in human hepatocellular carcinoma. Liver Int. 2004; 24: 432-436.

215. Wiesenauer CA, Yip-Schneider MT, Wang Y, Schmidt CM. Multiple anticancer effects of blocking MEK-ERK signaling in hepatocellular carcinoma. J Am Coll Surg. 2004; 198: 410-421.

216. Klein PJ, Schmidt CM, Wiesenauer CA, Choi JN, Gage EA, Yip-Schneider MT, Wiebke EA, Wang Y, Omer C, Sebolt-Leopold JS. The effects of a novel MEK inhibitor PD184161 on MEK-ERK signaling and growth in human liver cancer. Neoplasia. 2006; 8: 1-8.

217. Wentz SC, Wu H, Yip-Schneider MT, Hennig M, Klein PJ, Sebolt-Leopold J, Schmidt CM. Targeting MEK is effective chemoprevention of hepatocellular carcinoma in TGFalpha-transgenic mice. J Gastrointest Surg. 2008; 12: 30-37.

218. Huynh H, Chow PK, Soo KC. AZD6244 and doxorubicin induce growth suppression and apoptosis in mouse models of hepatocellular carcinoma. Mol Cancer Ther. 2007; 6: 2468-2476.

219. O’Neil BH, Goff LW, Kauh JS, Strosberg JR, Bekaii-Saab TS, Lee RM, Kazi A, Moore DT, Learoyd M, Lush RM, Sebti SM, Sullivan DM. Phase II study of the mitogenactivated protein kinase $1 / 2$ inhibitor selumetinib in patients with advanced hepatocellular carcinoma. J Clin Oncol. 2011; 29: 2350-2356.

220. Chen KF, Chen HL, Tai WT, Feng WC, Hsu CH, Chen PJ, Cheng AL. Activation of phosphatidylinositol 3-kinase/Akt signaling pathway mediates acquired resistance to sorafenib in hepatocellular carcinoma cells. J Pharmacol Exp Ther. 2011; 337: 155-161.

221. Schumacher G, Oidtmann M, Rosewicz S, Langrehr J, Jonas S, Mueller AR, et al. Sirolimus inhibits growth of human hepatoma cells in contrast to tacrolimus, which promotes cell growth. Transplant Proc. 2002; 34: 1392-1393.

222. Rizell M, Lindner P. Inhibition of mTOR suppresses experimental liver tumours. Anticancer Res. 2005; 25: 789793.

223. Semela D, Piguet AC, Kolev M, Schmitter K, Hlushchuk R, Djonov V, Stoupis C, Dufour JF. Vascular remodeling and antitumoral effects of mTOR inhibition in a rat model of hepatocellular carcinoma. J Hepatol. 2007; 46: 840-848.

224. Rizell M, Andersson M, Cahlin C, Hafström L, Olausson M, Lindnér P. Effects of the mTOR inhibitor sirolimus in patients with hepatocellular and cholangiocellular cancer. Int J Clin Oncol. 2008; 13: 66-70.

225. Sieghart W, Fuereder T, Schmid K, Cejka D, Werzowa J, Wrba F, Wang X, Gruber D, Rasoul-Rockenschaub S, Peck-Radosavljevic M, Wacheck V. Mammalian target of rapamycin pathway activity in hepatocellular carcinomas of patients undergoing liver transplantation. Transplantation. 2007; 83: 425-432.

226. Ribatti D, Nico B, Mangieri D, Longo V, Sansonno D, Vacca A, Dammacco F. In vivo inhibition of human 
hepatocellular carcinoma related angiogenesis by vinblastine and rapamycin. Histol Histopathol. 2007; 22: 285-289.

227. Yao DF, Wu XH, Zhu Y, Shi GS, Dong ZZ, Yao DB, Wu W, Qiu LW, Meng XY. Quantitative analysis of vascular endothelial growth factor, microvascular density and their clinicopathologic features in human hepatocellular carcinoma. Hepatobiliary Pancreat Dis Int. 2005; 4: 220 226.

228. Deli G, Jin CH, Mu R, Yang S, Liang Y, Chen D, Makuuchi M. Immunohistochemical assessment of angiogenesis in hepatocellular carcinoma and surrounding cirrhotic liver tissues. World J Gastroenterol. 2005; 11: 960-963.

229. Schoenleber SJ, Kurtz DM, Talwalkar JA, Roberts LR, Gores GJ. Prognostic role of vascular endothelial growth factor in hepatocellular carcinoma: systematic review and meta-analysis. Br J Cancer. 2009; 100: 1385-1392.

230. Malka D, Dromain C, Farace F,Horn S, Pignon J, Ducrex $\mathrm{M}$, Boiger V. Bevacizumab in patients (pts) with advanced hepatocellular carcinoma (HCC): preliminary results of a phase II study with circulating endothelial cell (CEC) monitoring. J Clin Oncol. 2007; 25 Suppl: 4570.

231. Siegel AB, Cohen EI, Ocean A, Lehrer D, Goldenberg A, Knox JJ, Chen H, Clark-Garvey S, Weinberg A, Mandeli J, Christos P, Mazumdar M, Popa E, Brown RS Jr, Rafii $\mathrm{S}$, Schwartz JD. Phase II trial evaluating the clinical and biologic effects of bevacizumab in unresectable hepatocellular carcinoma. J Clin Oncol. 2008; 26: 29922998.

232. Zhu AX, Blaszkowsky LS, Ryan DP, Clark JW, Muzikansky A, Horgan K, Sheehan S, Hale KE, Enzinger PC, Bhargava P, Stuart K. . Phase II study of gemcitabine and oxaliplatin in combination with bevacizumab in patients with advanced hepatocellular carcinoma. J Clin Oncol. 2006; 24: 1898-1903.

233. Hsu CH, Yang TS, Hsu C, Toh HC, Epstein RJ, Hsiao LT, Chen PJ, Lin ZZ, Chao TY, Cheng AL. Efficacy and tolerability of bevacizumab plus capecitabine as first-line therapy in patients with advanced hepatocellular carcinoma. Br J Cancer. 2010; 102: 981-986.

234. Sun W, Sohal D, Haller DG, Mykulowycz K, Rosen M, Soulen MC, Caparro M, Teitelbaum UR, Giantonio B, O’Dwyer PJ, Shaked A, Reddy R, Olthoff K. Phase 2 trial of bevacizumab, capecitabine, and oxaliplatin in treatment of advanced hepatocellular carcinoma. Cancer. 2011; 117: 3187-3182.

235. Thomas MB, Morris JS, Chadha R, Iwasaki M, Kaur H, Lin E, Kaseb A, Glover K, Davila M, Abbruzzese J. Phase II trial of the combination of bevacizumab and erlotinib in patients who have advanced hepatocellular carcinoma. J Clin Oncol. 2009; 27: 843-850.

236. Yau T, Wong H, Chan P, Yao TJ, Pang R, Cheung TT, Fan ST, Poon RT. Phase II study of bevacizumab and erlotinib in the treatment of advanced hepatocellular carcinoma patients with sorafenib-refractory disease. Invest New
Drugs. 2012; in press

237. Park JW, Finn RS, Kim JS, Karwal M, Li RK, Ismail F, Thomas M, Harris R, Baudelet C, Walters I, Raoul JL. Phase II, open-label study of brivanib as first-line therapy in patients with advanced hepatocellular carcinoma. Clin Cancer Res. 2011; 17: 1973-1983.

238. Toh H, Chen P, Carr BI, Knox JJ, Gill S, Qian J, Qin Q, Ricker JL, Carlson DM, Yong W. Linifanib phase II trial in patients with advanced hepatocellular carcinoma (HCC). J Clin Oncol. 2010; 28: 15s (Abstract 4038).

239. Hsu C, Yang TS, Huo TL, Hsieh RK, Hwang WS, Hsieh TY, Huang WT, Chao Y, Meng R, Cheng AL. Evaluation of vandetanib in patients with inoperable hepatocellular carcinoma (HCC): a randomized, double-blind, parallel group, multicentre, phase II study. Joint ECCO 15-34th ESMO Multidisciplinary Congress 2009; (Abstract PD6518).

240. Yau TC, Chen PJ, Chan P, Curtis CM, Murphy PS, Suttle AB, Gauvin J, Hodge JP, Dar MM, Poon RT. Phase I dosefinding study of pazopanib in hepatocellular carcinoma: evaluation of early efficacy, pharmacokinetics, and pharmacodynamics. Clin Cancer Res. 2011; 17: 6914-6923.

241. Philip PA, Mahoney MR, Allmer C, Thomas J, Pitot HC, Kim G, Donehower RC, Fitch T, Picus J, Erlichman C. Phase II study of Erlotinib (OSI-774) in patients with advanced hepatocellular cancer. J Clin Oncol. 2005; 23: 6657-6663.

242. Thomas MB, Chadha R, Glover K, Wang X, Morris J, Brown T, Rashid A, Dancey J, Abbruzzese JL. Phase 2 study of erlotinib in patients with unresectable hepatocellular carcinoma. Cancer. 2007; 110: 1059-1067.

243. Ramanathan RK, Belani CP, Singh DA, Tanaka M, Lenz HJ, Yen Y, Kindler HL, Iqbal S, Longmate J, Mack PC, Lurje G, Gandour-Edwards R, Dancey J, Gandara DR. A phase II study of lapatinib in patients with advanced biliary tree and hepatocellular cancer. Cancer Chemother Pharmacol. 2009; 64: 777-783.

244. Bekaii-Saab T, Markowitz J, Prescott N, Sadee W, Heerema N, Wei L, Dai Z, Papp A, Campbell A, Culler K, Balint C, O’Neil B, Lee RM, Zalupski M, Dancey J, Chen H, et al. A multi-institutional phase II study of the efficacy and tolerability of lapatinib in patients with advanced hepatocellular carcinomas. Clin Cancer Res. 2009; 15: 5895-901.

245. Asnacios A, Fartoux L, Romano O, Tesmoingt C, Louafi S S, Mansoubakht T, Artru P, Poynard T, Rosmorduc O, Hebbar M, Taieb J. Gemcitabine plus oxaliplatin (GEMOX) combined with cetuximab in patients with progressive advanced stage hepatocellular carcinoma: results of a multicenter phase 2 study. Cancer. 2008; 112: 2733-2739.

246. Chiorean EG, Ramasubbaiah R, Yu M, Picus J, Bufill JA, Tong Y, Coleman N, Johnston EL, Currie C, Loehrer PJ. Phase II Trial of Erlotinib and Docetaxel in advanced and refractory hepatocellular and biliary cancers: Hoosier Oncology Group GI06-101. Oncologist. 2012; 17: 13. 
247. Tovar V, Alsinet C, Villanueva A, Hoshida Y, Chiang DY, Solé M, Thung S, Moyano S, Toffanin S, Mínguez B, Cabellos L, Peix J, Schwartz M, Mazzaferro V, Bruix J, Llovet JM. IGF activation in a molecular subclass of hepatocellular carcinoma and pre-clinical efficacy of IGF1R blockage. J Hepatol. 2010; 52: 550-559.

248. Higano CS, Yu EY, Whiting SH, Gordon MS, LoRusso P, Fox F, Katz TL, Roecker JM, Schwartz JD. A phase I, first in man study of weekly IMC-A12, a fully human insulin like growth factor-I receptor IgG1 monoclonal antibody, in patients with advanced solid tumors. J Clin Oncol. 2007; 25: $\mathrm{s} 3505$.

249. Abou-Alfa GK, Gansukh B, Chou JF, Shia J, Capanu M, Kalin M, Chen HX, Zojwalla NJ, Katz S, Reidy DL, Kelsen DP. Phase II study of cixutumumab (IMC-A12, NSC742460; C) in hepatocellular carcinoma (HCC). J Clin Oncol. 2011; 29: (Abstract 4043).

250. Faivre S, Fartoux L, Bumsel F, Bouattour M, Dreyer C, Raymond E, Rosmorduc O. Phase I safety, and pharmacokinetic study of AVE1642, a human monoclonal antibody inhibiting the insulin-like growth factor-1 receptor (IGF-1R/CD221), administered as single agent and in combination with sorafenib as first line therapy in patients with advanced hepatocellular carcinoma (HCC). Hepatology. 2010; 52: 466A (Abstract 288).

251. Mulvihill MJ, Cooke A, Rosenfeld-Franklin M, Buck E, Foreman K, Landfair D, O'Connor M, Pirritt C, Sun Y, Yao Y, Arnold LD, Gibson NW, Ji QS. Discovery of OSI-906: a selective and orally efficacious dual inhibitor of the IGF-1 receptor and insulin receptor. Future Med Chem. 2009; 1: 1153-1171. 